\author{
Henryk Bąk ${ }^{1}$ \\ Warsaw School of Economics, Poland
}

Sebastian Maciejewski ${ }^{2}$

PGE Group, Warsaw, Poland

\title{
Endogeneity and Specialization in the European Monetary Union
}

\begin{abstract}
There has been a broad discussion about the viability of the European Monetary Union (EMU) in its present and prospective confines. Generally, the EMU, consisting of 19 countries, is not considered an optimal currency area due to low labor market flexibility, autonomous fiscal policies, and structural differences among its members. Considerations about the endogeneity effect of currency unions lead to the question whether the EMU will become more viable over time. According to the endogenity hypothesis formulated by Frankel and Rose [1996, 2000], a common currency area may gradually become an optimal currency area at some future point (expost unification), despite not having been an optimal currency area (OCA) prior to (ex ante) currency unification. Currency unification should bring about increased intra-industry trade and greater business cycle synchronization among member states. The most recent literature and analyses presented in this paper suggest that the endogenity effect in the EMU has been frail since its onset. While real convergence between EMU member states has not advanced, divergence in i.a. economic structures, national income and productivity levels is observed. The most important economic mechanisms reinforcing convergence and divergence among monetary union members are presented in this paper. Using recent data and related research results, we show a significant divergence in economic structures, business cycle synchronization and productivity levels among Eurozone members in the last decade. The Krugman sectorial dissimilarity index is applied to measure changes in industrial similarity among member countries and the Hodrick-Prescott filter to estimate business cycle synchronization in the
\end{abstract}


Henryk Bąk, Sebastian Maciejewski

EMU. These divergence tendencies have been strengthened by the global financial crisis of 2008 and persist, calling for reforms and new policies within the EMU.

Keywords: EMU, Optimal Currency Area, endogeneity, intra-industry trade, industrial specialization, business cycles

JEL: E32, F13, F36, F4, L6

\section{Introduction}

The Optimal Currency Areas ${ }^{3}$ (OCA) theory suggests that currency unification is favorable since it eliminates financial transaction costs, risk hedging, and barriers to free trade and capital flows, thereby leading to trade intensification between members. It also supports integration and the development of financial markets, contributes to business cycle conformity among union members (through augmentation of intra-industrial trade) and facilitates price and interest rate arbitrage, which enforces greater competition and is a guarantor of better capital allocation within the common currency area.

Independent monetary policy relinquishment is the primary argument against the adoption of a common currency. Countries that join a monetary union lose an effective tool for dealing with asymmetric shocks ${ }^{4}$, their independent monetary and exchange rate policies. In the absence of this instrument, countries in a monetary union must instead rely on other, more costly and less efficient adjustment mechanisms and buffers to asymmetric shocks, such as fiscal policies, factor and price flexibility, as well as financial markets. For this reason, monetary integration imposes costs on currency union members.

The 'One market, one money...' report of the Commission of the European Communities [1990] points to the fact that traditional OCA criteria are not measurable. The focus of this report is on the costs and benefits of monetary integration. The cost and benefit approach also dominated the discussion in the CEE countries upon their accession to the European Monetary Union (EMU, euro area, Eurozone). This approach also describes Poland's attitude towards euro adoption.

Historically, there have been two opposing points of view with reference to monetary integration. The so called 'economists' point of view, supported largely by German economists, emphasized harmonization of economic policies prior to monetary integration. The 'monetarists' point of view, supported by French and Italian economists, suggested that convergence of economic policies would be achieved after monetary unification [Molle, 1995, pp. 402-404]. Otherwise stated, 'economists' suggested waiting for monetary unification until sufficient real convergence was achieved between countries, while 'monetarists' emphasized that sufficient real convergence will be achieved after monetary unification. The 'monetarists' point of view was argued by the Commission of the European 
Communities [1990] in the 'One market, one money...' report, and has later been characterized by the endogeneity effect of currency unions [Frankel and Rose, 1996, 2000], that is the process by which the EMU will gradually become an optimal currency area at some future point (expost unification), despite not having been an optimal currency area prior to (ex ante) unification.

The recent European experience with monetary unification implies that formation of a common currency area may not be a seamless process. The present debate on the EMU is concentrated on difficulties that EMU states face in the early phase after monetary unification, rather than on gains Eurozone countries are expected to experience in the long-run.

At present, the euro area faces the problem of fiscal and banking sector stability and low economic growth. The first two problems have shaken the very foundations of the Eurozone since the global financial crisis in 2008. Also, divergence tendencies in the EMU have become more visible over time, and more intensified. Divergence has emerged between 'Northern', 'Southern' and 'Eastern' countries, and is visible i.a. in income and productivity levels, as well as in the competitiveness of EMU economies (see i.a. Beck [2013], Beck and Grodzicki [2014], Fingleton et al. [2014], Molle [2014]). This tendency started long before 2008+ and is expected to persist at least into the near future. The discussion about divergence in the EMU garnered more attention after 2008. It is also particularly important since the effective, long-run functioning of any EMU country largely depends upon the ability to maintain its relative competitiveness level.

This paper addresses the question of the significance of the endogeneity effect in the EMU, and presents the most important economic mechanisms potentially leading to either convergence or divergence in economic structures between union members. In this paper, the Krugman's sectoral ${ }^{5}$ dissimilarity index is used to assess sectoral convergence tendencies among Eurozone countries and Poland between 2003 and 2014. The notion of endogeneity is also presented in detail, and its impact on national income and business cycle convergence within the Eurozone is discussed. Finally, the volume of intra- and extraEMU trade evolution, and analysis of business cycle synchronization through application of the Hodrick-Prescott filter to GDP time series, are weaved into a discussion about the significance of currently prevailing convergence and divergence mechanisms. Results for selected EMU countries and Poland are presented for the period of 2003-2013.

\section{Literature Review}

Mundell [1961] initiated the discussion of the concept of monetary unification and Optimal Currency Areas in 1961, with his ground-breaking contribution "A Theory of Optimal Currency Areas". Since the early 1960 s, Optimal Currency Areas (OCA) theory has been meaningfully advanced and thoroughly analyzed, chiefly through application 
to the United States and the European Union. Broadly speaking, the OCA theory has progressed in three succeeding research streams. The first stream, coined Mundell I [McKinnon, 2008], was drawn from the early works of Mundell [1961], McKinnon [1963] and Kenen [1969]. The second research stream focused on evaluating the costs and benefits of monetary unification, and the third (current) research stream, which is continually being developed, refers to the debate concerning structural divergence and convergence, the endogeneity theory, and the concept of international risk sharing (Mundell II). Before the third research stream is discussed in detail, it is worth presenting the preceding two streams of OCA theory, which are presented in this section.

The early works of Mundell [1961], McKinnon [1963] and Kenen [1969] on OCA focused on the consequences of asymmetric (demand) shocks transmitted between regions within a single currency area. The potential smoothing effect of these shocks through economic mechanisms such as spatial mobility of labor and/or wage flexibility, as well as the economic openness and diversification of production and exports, was discussed in these studies.

Essentially, Mundell [1961] analyzed regions in the U.S. and Canada, rather than on independent countries (as it is often the case in the current discussion about the EMU). Mundell's focus was on the role of the labor market in facilitating adjustments to asymmetric shocks between regions sharing the same currency. Since regions in a single currency area cannot adjust to an asymmetric shock through currency devaluation, they must rely on labor mobility and/or (real) wage flexibility to mitigate the adverse effects of the shock, so as to return trade balances and employment to normal levels. Therefore, labor market flexibility was Mundell's [1961] criterion for currency area optimality.

Additional requirements for single currency area optimality were introduced by McKinnon [1963] and Kenen [1969]. McKinnon [1963] focused on openness criterion. As a general rule, the more open an economy is, the less effective floating exchange rate policies are in restoring internal (employment) and external (trade) balances. Since currency devaluation in a relatively open ${ }^{6}$ economy leads to considerably higher domestic inflation, as compared to a relatively closed economy, McKinnon opined that open economies (often small economies, highly dependent on foreign trade) are better suited for currency unification under domestic price stability criterion.

Kenen [1969] focused on the diversification of production patterns. Later studies, i.a. Vaubel [1988, p. 237], reformulated Kenen's [1969] criterion for determining whether sufficient diversification of production patterns, for exports and the domestic market, render a country more suitable for currency unification. In other words, countries with a high degree of specialization - especially in production patterns that differ from the patterns of other remaining countries within the currency union (criterion of homogeneity of production patterns), are especially prone to asymmetric shocks on their economies. For this reason, their presence in a monetary union is associated with high costs. 
Further discussion during the 1960 s on OCA theory defined additional optimality criteria. Among others, G. Haberler and M.J. Fleming focused on the nominal criterion of inflation convergence, suggesting that countries with similar tolerance to (historical records of) inflation are better suited for monetary union. Specifically, countries with consistently low and similar levels of inflation exhibit stable terms of trade requiring little exchange rate adjustment, which makes them suitable for monetary unification. J.C. Ingram underlined the importance of financial market integration in facilitating restoration of long-term interest rate disparities and the effective allocation of capital through unrestricted capital flows. Finally, D.A. Snider suggested that an optimal currency area can best be characterized by the effectiveness of the economic adjustment mechanisms that enable it to maintain full employment, price stability and a stable balance of payments. His contribution was to emphasize the need for monetary and fiscal policy centralization in a monetary union, and to identify the hazards of running decentralized and uncoordinated fiscal policies within a common currency area [Bąk, 2015, pp. 39-45].

As the number of optimality criteria increased, it became apparent that simultaneous fulfilment of all such is unlikely in practice. Thus, the OCA theory evolved by moving to the assessment of the costs and benefits resulting from monetary unification. This stream of research dominated the discussion of OCA theory in the $1970 \mathrm{~s}$ and $1980 \mathrm{~s}$. Monetary union members derive benefits from a common currency mainly at the microeconomic level. Unification reduced transaction costs, eliminates trade and capital movement impediments, and develops financial markets. It also allows better price transparency and price arbitrage, reduces exchange rate and price uncertainty, increases intra-union trade and brings the advantages of a larger monetary transaction domain.

Currency union costs are chiefly felt at the macroeconomic level. Since asymmetric shocks within the currency union cannot be blunted through national exchange rate policy, i.e. through nominal exchange rate fluctuations, these costs are strictly related to real exchange rate changes that occur among currency union members. "The need for real exchange rate adjustment depends on the size and frequency of changes in demand and supply conditions among the prospective member countries [asymmetric shocks] and the cost of alternative mechanisms of real adjustment to real economic shocks" [Vaubel, 1990, pp. 936-938]. In other words, the less costly monetary union is, the greater the extent of trade (openness), degree of labor mobility, real wage flexibility, effective international risk sharing mechanisms, and correlation of shocks and business cycles among member countries. International risk sharing refers i.a. to the role of financial markets (development and integration), fiscal policies, and individuals in cushioning asymmetric shocks occurring between countries in monetary unions (for more details see: Asdrubali et al. [1996], Kalemli-Ozcan et al. [1999, 2004] and Marinheiro [2003]). Adjustment to occurring shocks through the above-mentioned channels is considered a cost of the monetary union.

This second stream of research, focused on evaluation of costs and benefits of monetary unification, is characterized by Tavlas' [1993] conclusions, which enumerate prerequisites 
for OCA assessment, i.a. wage and price flexibility, production factor mobility, the diversification and homogeneity of production patterns, openness, the degree of fiscal integration, real exchange rate volatility (convergence is associated with low volatility, divergence with high volatility), inflation convergence, and political factors conducive to monetary integration. Some of these criteria are considered more important than others. Specifically, DeGrauwe considers downward real wage and price flexibility, as well as spatial labor mobility and sufficient coordination and/or centralization of fiscal policies, as prerequisites for the smooth functioning of a monetary union and, therefore, optimality of a common currency area [De Grauwe, 2014, pp. 3-22]. This direction of OCA analysis has not been developed in further theoretical research.

The relatively new, third stream of OCA theory research originated in the $1990 \mathrm{~s}$. It is mainly focused on whether member countries within a common currency area converge or diverge in economic structures (i.e. Bayoumi and Eichengreen [1992], Krugman [1991, 1993a], Krugman and Venables [1993b]). Regional specialization in production patterns was first addressed by Mundell [1961]. For this reason, the debate over divergence and convergence is also said to have its origin in the Mundell's approach [McKinnon, 2008]. It is quite natural that the European monetary integration is the main focus of this research trend, which is represented by two opposing views.

According to the 'Krugman's view', increased integration from monetary unification may lead to industrial specialization of the member countries. Specialization, and so regional divergence in economic structures, is likely to be fostered by concentration effects and externalities that determine the centralization of economic activities in regional clusters or cities. Divergence tendencies will lead to a situation where certain economic activities (e.g. financial services or chemical and automotive industries) concentrate in fewer localities, which are then transformed into specialized, large clusters of economic activity. Therefore, divergence leads to the concentration of certain economic activities and their monopolization within sectors. As a result, the economic structures of currency union members will become increasingly different, since the remaining countries will be left with other industries that are not subject to concentration effects. Regional specialization, in turn, will contribute to income divergence between regions, and also provoke asymmetric responses to economic shocks since countries with uneven economic structures will respond differently to changing economic conditions. These represent significant costs for a monetary union, since asymmetric shocks will have to be dampened by different economic mechanisms within the monetary union. In the worst case scenario, divergence could even threaten the existence of that union.

The Commission of the European Communities [1990] presents a different point of view in the 'One market, one money' report, which incorporates the endogeneity theory begun by Frankel and Rose [1996, 1997 and 2000], which favors a convergence scenario. Under it, an expected surge in intra-industry trade after monetary unification and the existence of centrifugal forces constraining further centralization are emphasized. 
According to the endogeneity theory of OCA, countries that choose to enter the common currency area should experience significant growth in intra-industry trade after unification. The expected surge in intra-industry trade is the consequence of monetary unification, which brings greater market transparency, less price uncertainty, and reduced transaction costs that significantly facilitate trade between members. As a result of increased intra-industry trade, countries are expected to converge in economic structures and exhibit greater business cycle synchronization. Frankel and Rose hypothesized that countries which did not meet the criteria for an optimum currency area ex ante could also create a monetary union, since convergence tendencies reinforce after monetary unification. For this reason, if the endogeneity effect prevails over various divergence tendencies over time, then the EMU will gradually become an optimal currency area at some point in the future (expost unification), despite not being an optimal currency area prior to (ex ante) unification. In other words, Tavlas' [1993] OCA assessment criteria need not be met prior to a monetary union's creation, since endogeneity will lead to the fulfilment of these criteria at some point in time after monetary unification.

The last OCA theory stream of research refers to international risk sharing, which focuses on the effectiveness of i.a. financial markets (development and integration) and fiscal policies in cushioning asymmetric shocks occurring between countries in monetary unions. International risk sharing through financial markets is effectuated through cross-ownership of assets on capital and money markets. According to i.a. Asdrubali et al. [1996], Kalemli-Ozcan et al. [1999, 2004] and Marinheiro [2003], financial markets may significantly buffer such asymmetric shocks if they are highly integrated. However, the role of financial markets in this respect became ambiguous after the outbreak of the 2008 global financial crisis [Marciniak, 2010], which shows that financial market integration may also cause shocks to spread, or be reinforced, across countries. The role of fiscal policy in smoothing asymmetric shocks is significant, and has been subject to detailed analysis also by Asdrubali et al. [1996], Kalemli-Ozcan et al. [1999, 2004] and Marinheiro [2003]. Fiscal policies can indeed smooth shocks but, if uncoordinated, they can also generate them. Discussion about the necessity of fiscal policy coordination and centralization, commenced by Snider, has been vigorous and detailed, i.a. by Eichengreen and von Hagen [1996], HM Treasury [2003] or Molle [2011, pp. 203-218].

\section{Divergence and Convergence Mechanisms in Monetary Unions}

An assessment of currency union optimality should account for both existing and expected future changes in the economic structures of its regions (or member states), and the potential of economic mechanisms within the union to even out asymmetric shocks within its borders. Monetary union costs will grow in the long run if regions within the 
monetary union diverge from each other in economic structures and business cycles, and economic mechanisms that can smooth asymmetric shocks arising between regions are not effective. As a rule, the more that states differ from each other within a common currency area, the more likely it is that regional and/or aggregate shocks will have an asymmetric impact on them.

In general, increased economic integration between countries may translate into either convergence or divergence of monetary union member countries' economic structures, business cycles and income. Mechanisms enforcing convergence and divergence tendencies in a monetary union have been the subject of detailed analysis and discussion i.a. in Bayou and Eichengreen [1992], Krugman [1991, 1993a], Krugman and Venables [1993b], Frankel and Rose [1996] and de Grauwe [2014]. These studies depict most important economic mechanisms as potentially playing a role in the EMU in the mid- to long-term future. The interplay of these mechanisms and external global economic conditions will determine whether convergence or divergence tendencies prevail in the Eurozone.

Important contributions to the new economic geography and clustering theory underlying the divergence discussion have been made i.a. by Krugman [1991, 1993a], Krugman and Venables [1993b]. The causal effect between increased integration and specialization is characteristic to many industries, including manufacturing, farming, wholesale and retail trade, and financial services. For one thing, the growing importance of high-technology industries and observed specialization and centralization tendencies prevailing in these sectors reinforce the need for wider comprehension of the factors determining industrial localization. For another thing, differences in economic development between northern and southern regions in Italy and eastern and western German states persist in the mid-term, despite political integration of these regions and extensive fiscal federalism employed in the case of Germany. These tendencies call for wider comprehension of their determinants as well.

Essentially, eliminating law and economic barriers between regions boosts trade and likely fosters specialization, i.e. divergence of economic structures. If positive externalities linked with concentrating certain economic activities outweigh negative ones, then these activities are likely to move to centers offering such externalities. This will result in a concentration of these activities in a smaller number of regions. Specifically, high-technology industries including IT, financial services, and the chemical and automotive industries serve as appropriate examples. If a high-technology industry is subject to significant externalities, then economic integration will lead to its concentration in fewer regions. As a result of concentration, regional incomes will diverge from each other because the remaining regions will be left with low-technology industries. Consequently, regional specialization will lead to income divergence between regions, and it will also provoke asymmetric responses to economic shocks since countries with uneven economic structures will respond differently to changing economic conditions. 
Specifically, there exist several externalities that determine the centralization of economic activities in regional clusters or cities. Many of them have an effect on other externalities, creating spill-over effects reinforcing the impact of remaining externalities. The below-mentioned externalities differ in significance depending on the industry.

First, access to infrastructure, such as transport and communications, creates incentives for companies to concentrate in the same area. This occurs because developed infrastructure reduces the costs of economic activity. Large economic clusters allow access to advanced infrastructure, which draws especially high-technology industries that require instantaneous access to telecommunication networks and manifold support services. Such economic clusters are therefore their natural locations. Second, a relatively large region is an attractive place to produce, due to both the existence of a large market and the diversity of goods produced there. Third, concentration creates competitive markets for intermediate goods and increases competition between companies. Through increased competition, business costs decrease, and both the variety and quality of products are augmented. Fourth, labor force demand increases as companies join in the market. Growing labor demand increases wages to attract the required labor. As labor supply rises, so does regional demand for infrastructure, services and goods, which stimulates further production. It is likely that the growth effect resulting from centralization may be at the expense of other smaller regions. Fifth, high-technology industries require highly-skilled labor and access to research facilities that are available in large agglomerations. Large markets offer more possibilities for network learning and technology spillovers (collaboration between firms and/or industries or collaboration with universities). Network learning and technology spillovers foster innovation and enforce further industry growth [HM Treasury, 2003b, p. 21-26].

The above-mentioned externalities reinforce each other, creating a circular effect leading to further centralization. This growth effect will be sustained until concentration externalities outgrow decentralization externalities. ${ }^{7}$ Among others, the financial centers of London, Frankfurt and New York constitute strong evidence of this circular causation phenomenon [HM Treasury, 2003b].

Unlike in the services sector, concentration in the manufacturing industry depends mainly on transaction costs (transportation, tariffs, differences in law and regulations) and concentration externalities, including economies of scale. The concentration effect in the manufacturing industry is greater when concentration externalities and the lower transportation costs are more significant [Krugman, 1993a]. Crucial questions, in this respect, are how strong concentration tendencies may be and what drives industries to concentrate in fewer regions.

According to Krugman [1991], the strength of concentration tendencies in manufacturing industries depend i.a. on the fraction of the population working in the manufacturing industry, transportation costs and economies of scale. The less significant the economies of scale are, and the higher the relative transportation costs, the smaller the 
concentration effect. Both of these factors determine whether production should be located close to a market or in large agglomerations. In the case of high economies of scale and relatively low transportation costs, manufacturing will concentrate in large cities. The greater the trend towards concentration, the larger the share of the population employed in non-agricultural sectors and the higher the fraction of income spent on non-agricultural goods and services. A relatively large region with a substantial population working in non-rural sectors will be an attractive place to produce, due to both the existence of a large market and the diversity of goods produced there. As a result, labor force demand will augment as companies enter the market. As labor supply rises, regional demand and the need for further production will increase, reinforcing concentration tendencies [Krugman, 1991, pp. 485-487].

It is likely that the delineated concentration effect may occur at the expense of other regions. Industry concentration, and so regional specialization, may take place in regions with different or similar endowments, which may initially specialize in different, or the same, industries. A conceptually interesting example [Krugman, 1993a] depicts two industries with similar endowments located in different regions. Demand for goods manufactured in these two regions is assumed to be perfectly price-inelastic, leading to perfect competition between industries, which are subject to location external economies.

\section{FIGURE 1. Geographical concentration}

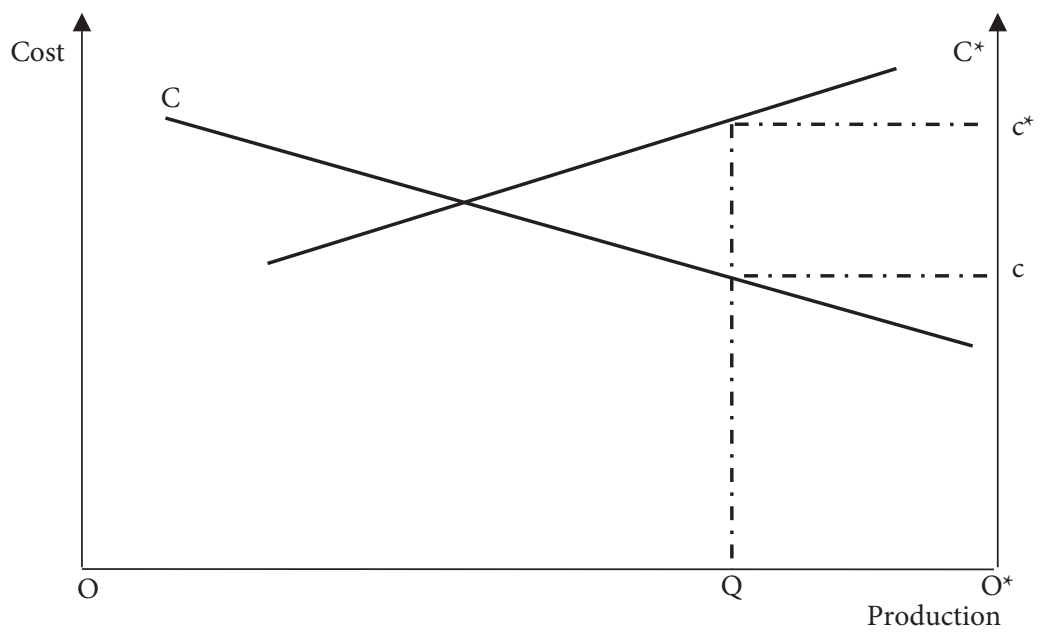

S o u r ce: Figure from Krugman, 1993a, p. 245.

The example describes two industries producing homogenous goods in different locations with different local price-inelastic demands. In total $\mathrm{OO}^{*}$ of goods is sold, where industries produce $\mathrm{OQ}$ and $\mathrm{QO}^{\star}$ quantities at different marginal costs $\mathrm{c}$ and $\mathrm{c}^{\star}$, respectively. 
$\mathrm{C}^{\star}$ and the $\mathrm{C}$ lines denote the supply curves of each regional industry. Specifically, curves $\mathrm{C}$ and $\mathrm{C}^{\star}$ may be different due to some factor of cost advantage.

The amount $\mathrm{QO}^{*}$ is supplied by the industry, which is characterized by the supply curve $C^{*}$. Similarly, the amount OQ is supplied by the industry, characterized by the C curve. The reasons why these two quantities are different may be i.a. due to the size of each market or differences in production costs (supply curve characteristics). The difference in production costs $c$ and $c^{\star}$ at which goods are supplied in regional markets is persistent due to relatively high transaction costs, which are assumed at the start of this analysis. Relatively high transaction costs (i.a. transportation, tariffs, differences in law and regulations) will prevent equal prices across markets.

However, if transaction costs can be lowered through e.g. better transport or greater market integration, then industry (denoted by the $\mathrm{C}$ curve) will likely expand at the cost of industry $C^{\star}$. Eventually, declining transaction costs may lead industrial activity in the region with industry $\mathrm{C}^{\star}$ to be expeled by industry $\mathrm{C}$ from the second region [Krugman, 1993a, pp. 244-247]. In this way, industrial activities are likely to concentrate in regions where some initial advantages exist, although endowments may be similar. This is possible only if transportation costs and regulatory impediments are low and concentration externalities are significant. In Krugman's view, monetary unification and integration of national markets will lead to greater specialization within the EMU and cause regional crises to be more common in the future. As a result, economic conditions in certain parts of the EMU will be more unstable, and greater divergence in regional growth rates will be observed in the forthcoming years.

Finally, factor mobility (capital and labor mobility) is another significant element that may lead to regional divergence. Krugman [1993a, p. 247-249] mentions that increased factor (capital and labor) mobility will reinforce, and make permanent, the impact of asymmetric shocks. Suppose that an economic shock hits two regions with different economic structures in an asymmetric way. If capital is mobile, it will outflow from the region negatively affected by the shock to the region positively affected by the shock, where return on capital is higher. ${ }^{8}$ In this way capital will augment region-specific shocks. Moreover, in the long run, labor mobility will make the impact of the shock permanent, as it moves outward to equalize the consequences of this adverse shock. The negatively affected region will shed people to adjust to new economic conditions. As a result, large fluctuations in aggregate regional products will take place among regions.

If production factors were immobile, real or nominal wages and prices would have to bear the burden of adjustment to an asymmetric shock. Real or nominal wages and/or prices would have to decrease in the region negatively affected by the shock. Consequently, lower wages would attract other industries, leading to increased diversification of this region in terms of industrial structures. Regional aggregate products within the currency union would not be subject to significant changes [Krugman, 1993a, pp. 247-249]. 
Speaking of the EMU, there are no barriers to capital flows, however labor remains relatively immobile [HM Treasury, 2003a]. This is because cultural and language differences are still relatively strong impediments to European labor mobility. In addition, labor mobility depends on readiness to migrate, which is i.a not solely determined by the financial conditions of individuals. This is a significant constraint to labor mobility, which narrows its effectiveness to respond to shocks between regions, even in the long run.

To sum up the above-mentioned divergence scenario arguments, one might expect the EMU to experience a significant surge in regional specialization as the process of integration within Eurozone advances on all markets and factor mobility increases. This would imply more region- (country-) specific shocks within the confines of the EMU, and an increased need for real exchange rate adjustment.

Arguments in favor of convergence in the euro area emphasize the importance of intra-industry trade, formation of interregional clusters of economic activity, existence of centrifugal forces constraining further centralization, and the growing importance of the services sector. The arguments underlying the convergence scenario rest on economic and geographic mechanisms.

An important point of view favoring the convergence scenario was presented by the European Commission [Commission of the European Communities, 1990, pp. 136-178, pp. 235-249]. According to this report, the frequency of asymmetric shocks among EMU countries will decline over time, since national borders will become insignificant in the future. Consequently, intra-industry ${ }^{9}$ trade will play an increasingly important role among member countries. The growing presence of intra-industry trade, unlike inter-industry trade and trade resulting from dividing production process into phases ${ }^{10}$, decreases the likelihood of asymmetric shocks. Accordingly. shocks to one industry will affect many countries in a very similar manner.

Following a similar line of reasoning to that of the European Commission, Frankel and Rose [1996] formulated the hypothesis that countries which did not meet the criteria for an optimum currency area, ex ante unification, could also create a monetary union. In particular, accelerated growth of mutual intra-industry trade resulting from the elimination of transaction costs and exchange rate fluctuations should encourage a gradual convergence of business cycles (i.e. co-movement of national outputs) and provide significant benefits from monetary unification. OCA criteria would be thus met ex post, although not fulfilled ex ante currency unification. Deepening the scope of convergence of economies that form a common currency area is the essence of the monetary union endogeneity theory.

Next, de Grauwe [2010, pp. 23-27] suggests that there exists a presumption in favor of the European Commission's view. Although integration brings specialization, two further arguments make the divergence scenario more unlikely. First, economic integration in the euro area will become blind to national borders over time. Clusters of economic activity will encompass different countries, reducing asymmetries. Second, the growing importance of services in contemporary economies will support convergence. Since services 
do not necessarily undergo a concentration process, this will mitigate centralization and divergence tendencies and reinforce convergence.

Furthermore, there are natural decentralization forces (negative externalities) that may constrain centralization tendencies within the EMU. Among others, infrastructure congestion, high property, labor and regulation prices or relative lack of supply of qualified labor can induce the decentralization of economic activities. Other familiar factors, such as advances in telecommunications leading to a 'death of distance,' also lessen the impact of centralization forces [HM Treasury, 2003b, pp. 21-26].

\section{Endogeneity of Currency Unions}

Essentially, the endogeneity of currency unions describes the effect monetary unification has on its members' bilateral trade and business cycles. Countries that enter a common currency area should experience a surge in (intra-industry) trade and business cycles more similar to those of other union members after unification. These changes should be determined by two mechanisms. First, joining a monetary union implies greater market transparency, less price uncertainty and reduced transaction costs. ${ }^{11}$ These should intensify investment and amplify intra-industry trade between members. ${ }^{12}$ Consequently, more intra-industry trade should result in greater synchronization of business cycles among currency union members. Secondly, independent monetary policy relinquishment is likely to strengthen the convergence of business cycles between states within the common currency area. This stems from the fact that when monetary policies are run by independent central banks, they tend to generate shocks between states, rather than smooth them [Frankel and Rose, 1996, pp. 1-5].

Theoretically, greater market transparency, less price uncertainty, reduced transaction costs and/or relinquishment of an independent monetary policy may strengthen or weaken business cycle symmetry across countries in a currency union. This is dependent on specific economic factors that require clarification before discussing the endogeneity effect in detail.

If currency unification led mainly to increased inter-industry trade, asymmetric specialization within the monetary union would follow. For one thing, according to the Heckscher-Ohlin model of trade, the more specialized countries become, the greater is the trade between them. In this model, specialization in production patterns appears when countries have comparative advantages in producing specific goods. This trade pattern characterizes underdeveloped economies. Growing specialization enforces more heterogeneity of economic structures between countries and leads to more frequent asymmetric shocks, causing business cycles to diverge within a currency union. Conversely, if currency unification leads increased intra-industrial trade, which is likely to be the case for developed economies, i.e. also for EMU [Commission of the European Communities, 1990, 
pp. 220-232], then member countries' economic structures would converge to each other, such that shocks will affect those countries in a similar manner. As a result, correlation of national business will increase. The crucial question arising in the EMU context, raised by Krugman [1991, 1993a], Krugman and Venables [1993b], is whether trade intensification will indeed reveal itself in greater intra-industrial trade or in national specialization based on the comparative advantage concept and localization externalities.

Independent monetary policies can generate shocks, as well as smooth them. Depending on the net effect, renouncing monetary policy renouncement may (or may not) be favorable to business cycle convergence of countries entering a monetary union. Provided that independent monetary policies are chiefly responsible for observed fluctuations in the real exchange rates between countries, the endogeneity effect will be strong. However, if nominal exchange rates serve as an efficient tool facilitating macroeconomic adjustment between regions, then candidate countries for the currency union would be better-off retaining their independent monetary policies. In this way, countries could better control domestic inflation and stabilize domestic output more effectively. For example, Poland's experience from the outbreak of the global crisis in 2008 is that the PLN floating rate has significantly facilitated adjustment to the external global shock affecting Poland and the EMU [Konopczak, Marczewski, 2011, pp. 14-18; Brzoza-Brzezina et al., 2012]. In contrast, the EMU countries that were hit hardest by the global crisis could not devaluate the euro. Instead, they were forced to use fiscal policies and to pursue internal devaluation as a response to the crisis. In the Baltic states and Southern countries internal devaluation took place, restoring their current account of the balance of payments equilibria.

The endogeneity mechanism effectuates economic convergence through two channels. The first is through growing trade linkages due to monetary unification. The second is related to both trade and national income being endogenous with respect to each other.

As to the first effect, i.e. the effect of monetary unification on trade, Frankel and Rose's [2000] gravity model estimation results (from a panel of over 200 countries being part of currency unions all over the world) show that trade between countries joining a monetary union is expected to grow 240 percent on average. This effect does not come at the expense of trade with non-union partners. An effect of similar size, supporting the findings of Frankel and Rose has been obtained by Barro and Tenreyro [2007] in a refined gravity model study. Both studies suggest that increased trade-integration between currency union members should result in a growing symmetry of their business cycles.

Frankel and Rose [2000] estimate that after joining the Eurozone, Poland's openness to the euro area, measured in terms of imports and exports to GDP, would rise from 60 (in 1995) to 112 percent over a 20 years horizon. This strongly favors Poland's accession to the euro area. Further studies published after 2000 show that the trade effect due to endogeneity on the EMU is considerably smaller than Frankel and Rose [2000] suggested. Their results may be biased upwards for at least four reasons. 
First, the authors estimated the effect of currency unification on trade using a sample of countries located in different geographical regions, with economic structures that differ considerably from those of the Eurozone countries, and exhibiting significant degrees of variation of economic development. This introduces a likely bias in gravity model estimates (for the Eurozone), since the underlying data is a panel of many heterogeneous countries from all over the world [Czarny et al., 2013, p. 65-86; Cieślik et al., 2014, p. 10-14], suggesting that such estimations should be constrained to selected group of developed countries. Moreover, many of the subject countries have been part of pegged currency regimes, and are not members of monetary unions (single currency areas).

Second, Frankel [2010] mentions that European countries are larger than the average country subject to analysis by Frankel and Rose [2000], and are therefore less reliant on trade than smaller countries. And the decision to adopt a common currency may also depend on the extent of current and potential future trade between countries.

Third, the endogeneity effect has been estimated for the period of 1970-1995, when global macroeconomic conditions and financial and transport technology were different from the conditions prevailing from 1999 onwards. Also, the construction of the European Monetary System (EMS) differs from that of the current EMU. During the functioning of the EMS (1979-1998), periodic adjustments in exchange rates took place. The longest term without adjustments was between 1987 (after the stock market crisis) and the economic crisis in Europe of 1992. The policy response to the 1992 crisis was to devalue weak, and revalue strong currencies and establish new, wider fluctuation bands to restore the economic balances of member states. This system is no longer available in the EMU.

Fourth, the endogeneity effect has been estimated for countries at different stages of mutual economic integration. It is likely that since EMU economies have exhibited a significant level of mutual economic integration prior to currency unification, a substantial part of benefits captured by Frankel and Rose's [2000] estimate of currency unification on trade may already have been realized prior to the creation of the EMU. Thus, the effect of the EMU's creation on trade from 1999 onwards is, in fact, smaller than that of 240 percent. Similarly, the effect of joining the euro area on trade should also be smaller than Frankel and Rose's estimate for prospective Eurozone members, including Poland and the Czech Republic, from the CEE region. This is because Poland and the Czech Republic already exhibit a significant level of mutual economic integration with the EMU. Similarly, in a recent study on Slovakia and Slovenia's EMU accession (being the largest CEE countries to have so far entered the EMU) Cieślik et al. [2012, 2014b] find that the effect of joining the Eurozone on bilateral trade is insignificant for these countries. They argue that late accession to the Eurozone, and the coincidence of the global financial crisis with these countries' entry, are likely factors responsible for this finding of an insignificant bilateral trade effect, which may also, be due to an already significant level of mutual economic integration of these countries with EMU, prior to their accession to the euro area. 
On average, the already realized endogeneity effect of currency unification on increased trade is estimated to range from: 5 to 20 percent for the Eurozone [De Grauwe, 2014, p. 66] (Nitsch and Pisu [2008]; 5-10 percent over 1995-2005, Rose [2008] 8-23 percent until 2008, Frankel [2010] 15 percent). This much smaller effect, as compared to the 240 percent estimated by Frankel and Rose, still constitutes a significant boost to intra-EMU trade.

The effect of currency unification on trade is most pronounced on the micro level in mid- and small-sized firms. For one thing, according to Nitsch and Pisu [2008], the euro zone has increased the exposure of smaller and less productive firms to foreign (intra-Eurozone) markets and augmented the number of products exported to other EMU countries. ${ }^{13}$ Since trade costs across borders have decreased after unification, firms characterized by lower unit values have increased their presence in foreign markets, thereby contributing to the increase in overall intra-Eurozone trade. Moreover, as competition among firms has increased on the intra-EMU markets with the introduction of the euro, firms have reduced their product offer and concentrated on most profitable competencies. Modified gravity model estimates by Nitsch and Pisu [2008] show that the realized effect of the euro on trade creation is equal to 5-10 percent for the period of 1995-2005. ${ }^{14}$

For another thing, according to Baldwin et al. [2008] the rise in trade resulting from introduction of the euro and consequent trade costs reduction (transaction and hedging costs) is limited, and confined to sectors characterized by product differentiation and imperfect competition. Second, a common currency impacts trade through the 'newly-traded goods' channel. In other words, trade creation is effectuated by firms exporting a wider range of their manufactured goods to other member countries than was done earlier [Baldwin et al., 2008, p. 59-75].

Interestingly, results similar to these of Nitsch and Pisu [2008] and Baldwin et al. [2008] have been obtained by Duchnowska [2014, pp. 173-194] for Polish mid-sized exporters. A more efficient use of current production capacities is the most important determinant of Polish exporters' pricing strategies on foreign markets. It is by exports of products that entrepreneurs increase their production capacities and lower the unit cost of manufactured goods. This increases their firms' competitiveness, profitability, and shares on foreign markets. In a similar vein, a recent study by Cieślik et al. [2014a], based on 2002-2009 data for Slovakia and Slovenia (the NMS of the Eurozone) shows that the effect of accession to the EMU positively impacts the propensity of domestic firms to export to foreign markets, due to lowered transaction costs. They also find that the firm productivity, human capital, foreign technology and innovation levels are significant factors affecting the probability to export. ${ }^{15}$

As for the second aspect of endogeneity, Frankel and Rose [2000] find that the average effect of openness (trade-to-GDP ratio) on real GDP is positive. ${ }^{16}$ Although this effect is a statistical relation, and not a causal effect, it is quite plausible to assume that greater trade (through technology, new product diffusion, and greater investment and market transparency) will positively contribute to GDP growth among currency union members. 
Since trade is also positively related to the size of the economy and country's national per capita income, endogeneity likely contributes to greater business cycle convergence indirectly. As unification triggers trade growth, higher trade positively affects real GDP growth. Greater national income would, in turn, heighten trade [Frankel and Rose, 2000].

Should Frankel and Rose's [2000] endogeneity effect estimates be unbiased, Poland's GDP would increase by 20 percent more over a 20 -year horizon after joining the EMU, as compared to staying outside. It should be noted, however, that this effect encompassed effects of Poland's accession to the EU, trade liberalization within the WTO, and a transformed Polish economy. The two first effects have been already been largely realized.

\section{Endogeneity and Financial Markets}

Essentially, currency unification should lead to a greater depth and liquidity of capital and money markets. Greater depth and liquidity should, in turn, improve access to capital, lower its cost and improve capital allocation within the currency union, thereby fostering trade and economic growth [De Grauwe and Mongelli, 2007].

During the first years of the Eurozone functioning, the euro has facilitated the integration of money and capital markets. Signs of financial market integration were visible in the declining dispersion of interest rates among Eurozone members, both on inter-bank markets and for national treasury bonds [Pagano, von Thadden, 2004, p. 18]. Also, financial market integration fostered the growth of capital market debt financing for sovereign and private sectors [Pagano, von Thadden, 2004, pp. 3-17]. The euro is also gradually eliminating home-bias from institutional and individual investor behavior on financial markets, leading to greater portfolio diversification by EMU investors [Schoenmaker, Bosch, 2008; Moerman, 2008].

Furthermore, the foregoing financial market integration and declining home bias should strengthen international risk sharing through financial markets among euro area countries effectuated by cross-ownership of assets on capital and money markets. Since individuals prefer a relatively steady amount of consumption over time, they will hedge against the risk of a drop in consumption from asymmetric shocks hitting their regional economies. This hedge is effectuated through purchases of bonds, stocks and derivative instruments that embody claims on the assets and revenue of other businesses, or by smoothing private consumption inter-temporarily by saving or investing (see: Asdrubali et al. [1996], Kalemli-Ozcan et al. [1999, 2004] and Marinheiro [2003]).

Interestingly, the perceived smoothing potential of financial markets changed after the 2008 global financial crisis. Contagion from the US economy resulted in liquidity and fiscal crises and major recession across the whole Eurozone, with significant, negative asymmetric impacts on the EMU's 'Northern' and 'Southern' economies. In other words, integrated financial markets actually reinforced, and spread the US financial crisis, rather 
than smoothed it. This experience casts doubt on the future ability of international financial markets to smooth large shocks between countries, and their contribution to cyclical convergence or divergence [Lubiński, 2010, pp. 84-98].

\section{Measures of Current Real Convergence and Divergence in the EMU}

What is most important in the context of long-run efficient functioning of the Eurozone is a sufficient level of real economic convergence. This guarantees that economic shocks impacting the EMU have a symmetric, rather than an asymmetric effect on its members, requiring less adjustment from economic mechanisms to smooth their adverse effects on particular countries.

There exist several real economic convergence criteria stemming from the OCA theory fulfillment of which determines whether a single currency area is optimal. Among them the most important are: (1) convergence in economic structures; (2) productivity; (3) levels of economic development; (4) convergence in business cycles; (5) labor market flexibility (spatial mobility and real wage flexibility); (6) diversification of exports and imports; (7) correlation of demand and supply shocks; and (7) effectiveness of channels smoothing asymmetric shocks. Although these criteria do not constitute the set of legal conditions stipulated in Art. 141(1) of the Treaty [TFEU, 2010], and are not required by a country aspiring to accede the EMU, their fulfillment is crucial to successful monetary unification in the long-run [Bąk, 2008, pp. 15-23]. A more comprehensive assessment of real convergence should also include i.a. a detailed analysis of regulatory and institutional similarity of EMU states [Marczewski, 2010, pp. 9-11].

Four of these real convergence criteria are analyzed in greater detail below, using the most recent data and research results from related studies. To assess whether convergence or divergence tendencies prevailed in the Eurozone over the past 10-15 years, we first analyze sectoral convergence through a sectoral dissimilarity index and present research results on convergence in productivity, levels of economic development and labor market structures. An analysis of business cycle correlation is then presented. Finally, we point out an interesting trend taking place in intra-and extra-EMU trade that may have impacts on real convergence between Eurozone countries.

First, tendencies in sectoral similarity, presented below, are assessed using the pairwise-Krugman specialization index. This is one of many measures to assess sectoral dissimilarity or specialization [Beck, 2013, pp. 32-34]. The bilateral sectoral dissimilarity index is computed on a sectoral decomposition of GDPs' (according to the ISIC Rev 4 industrial classification system) of selected EMU countries for the years 2003, 2008 and 2013. The index has been applied i.a. by Krugman [1993a] to measure industrial specialization 
tendencies in the US and EU economies. The index $S_{i j, y}$ denoting sectoral dissimilarity of country $i$ relative to country $j$ in year $y$ is defined as follows:

$$
S_{i j, y}=\sum_{k=1}^{10}\left|s_{k i, y}-s_{k j, y}\right|
$$

where $s_{k i, y}$ is the share of $k$-th industry (10 sectors in total resulting from the ISIC Rev 4 breakdown) in total GDP of country $i$ in year $y$ (i.e. 2003, 2008 or 2013). Specifically, only 2003, 2008 and 2013 data is subject to this analysis, as the most recent data at our disposal is from 2013. By assuming a 5 year horizon for our analysis, we compare sectoral dissimilarity indices from 2013 with that of 2008 (being the year before the global financial crisis hit real European economies' sectors hardest), and 2008 with that of 2003 (one year before the European Union's Eastern enlargement):

$$
\Delta S_{i j, y}=S_{i j, y}-S_{i j, y-1}
$$

where $\Delta S_{i j, y}$ denotes the change in sectoral dissimilarity index of country $i$ relative to country $j$ between years $y$ and $y$ - 1 . Let $\Delta S_{i j, y}$ be 'CC' if $\Delta S_{i j, y} \leq-5 \%, \Delta S_{i j, y}$ be 'C' if $\Delta S_{i j, y} \in(-5 \%, 0]$, $\Delta S_{i j, y}$ be 'D' if $\Delta S_{i j, y} \in(0 ; 5 \%)$, and $\Delta S_{i j, y}$ be 'DD' if $\Delta S_{i j, y} \geq 5 \%$. The $\pm 5 \%$ threshold values are chosen arbitrarily, based on an analysis of tables $1 \mathrm{a}$ and $2 \mathrm{a}$, attached in the appendix. We present $\Delta S_{i j, y}$ values replaced by 'C', 'CC', 'D' or 'DD' in tables 1 and 2 . In these tables the letters D or DD (C or CC) are interpreted as an increase or a relatively strong increase (decrease or a relatively strong decrease) of the sectoral dissimilarity between years $y$ and $y-1$ in the respective bilateral comparison. ${ }^{17}$ Numerical values of $\Delta S_{i j, y}$ are presented in tables $1 \mathrm{a}$ and $2 \mathrm{a}$ in the appendix of this paper.

Essentially, the results presented in tables 1 and 2 show that divergence tendencies prevailed in the Eurozone over the last decade. Index values for the intervals 2003-2008 (table 1) and 2008-2013 (table 2) denote increasing dissimilarities in economic structures between the selected EMU members.

In total, 58 out of 105 bilateral comparisons exhibit increased sectoral dissimilarity (divergence) in 2008, compared to 2003. 41 of 58 bilateral comparisons were characterized by divergence, and 17 by relatively strong divergence. Increasing bilateral sectoral dissimilarity was especially visible in the case of the Slovak Republic, Germany, France (and also Poland) between 2003 and 2008. By contrast, bilateral convergence was observed for 47 pairs of countries, of which 16 were characterized by relatively strong convergence. Ireland, Spain and Italy recorded bilateral sectoral convergence with more than half of the examined countries. Overall, our results for 2008 vs. 2003 are similar to those obtained by Beck and Grodzicki [2014, pp. 39-41] for the period of 1991-2007. 
TABLE 1. Bilateral sectoral dissimilarity index S (ij) - 2003 vs. 2008

\begin{tabular}{|c|c|c|c|c|c|c|c|c|c|c|c|c|c|c|c|c|}
\hline 2003-2008 & AUT & BEL & EST & FIN & FRA & DEU & GRC & IRL & ITA & LUX & NED & PRT & SVK & SVN & ESP & POL \\
\hline Austria & & $\mathrm{D}$ & $\mathrm{C}$ & $\mathrm{C}$ & $\mathrm{D}$ & $\mathrm{D}$ & $\mathrm{D}$ & $\mathrm{C}$ & $\mathrm{C}$ & $\mathrm{D}$ & $\mathrm{C}$ & D & DD & $\mathrm{C}$ & $\mathrm{C}$ & $\mathrm{D}$ \\
\hline Belgium & $\mathrm{D}$ & & $\mathrm{CC}$ & $\mathrm{D}$ & $\mathrm{D}$ & $\mathrm{DD}$ & $\mathrm{CC}$ & $\mathrm{CC}$ & $\mathrm{D}$ & $\mathrm{D}$ & C & $\mathrm{C}$ & DD & D & $\mathrm{CC}$ & D \\
\hline Estonia & $\mathrm{C}$ & $\mathrm{CC}$ & & $\mathrm{D}$ & $\mathrm{D}$ & $\mathrm{D}$ & $\mathrm{DD}$ & $\mathrm{C}$ & $\mathrm{C}$ & D & $\mathrm{CC}$ & $\mathrm{C}$ & D & $\mathrm{CC}$ & $\mathrm{CC}$ & $\mathrm{DD}$ \\
\hline Finland & $\mathrm{C}$ & $\mathrm{D}$ & $\mathrm{D}$ & & $\mathrm{D}$ & $\mathrm{C}$ & $\mathrm{C}$ & $\mathrm{D}$ & $\mathrm{C}$ & $\mathrm{DD}$ & $\mathrm{C}$ & $\mathrm{C}$ & $\mathrm{DD}$ & $\mathrm{D}$ & $\mathrm{CC}$ & $\mathrm{D}$ \\
\hline France & $\mathrm{D}$ & $\mathrm{D}$ & $\mathrm{D}$ & $\mathrm{D}$ & & $\mathrm{DD}$ & $\mathrm{CC}$ & $\mathrm{CC}$ & $\mathrm{D}$ & $\mathrm{D}$ & $\mathrm{D}$ & $\mathrm{D}$ & $\mathrm{DD}$ & $\mathrm{DD}$ & $\mathrm{C}$ & DD \\
\hline Germany & $\mathrm{D}$ & $\mathrm{DD}$ & $\mathrm{D}$ & $\mathrm{C}$ & $\mathrm{DD}$ & & $\mathrm{D}$ & $\mathrm{C}$ & $\mathrm{D}$ & $\mathrm{DD}$ & $\mathrm{D}$ & $\mathrm{D}$ & $\mathrm{D}$ & $\mathrm{D}$ & $\mathrm{C}$ & $\mathrm{D}$ \\
\hline Greece & $\mathrm{D}$ & $\mathrm{CC}$ & $\mathrm{DD}$ & $\mathrm{C}$ & $\mathrm{CC}$ & $\mathrm{D}$ & & $\mathrm{C}$ & $\mathrm{C}$ & $\mathrm{DD}$ & $\mathrm{CC}$ & $\mathrm{C}$ & $\mathrm{DD}$ & $\mathrm{D}$ & $\mathrm{D}$ & DD \\
\hline Ireland & $\mathrm{C}$ & $\mathrm{CC}$ & $\mathrm{C}$ & $\mathrm{D}$ & $\mathrm{CC}$ & $\mathrm{C}$ & $\mathrm{C}$ & & $\mathrm{CC}$ & $\mathrm{C}$ & $\mathrm{CC}$ & $\mathrm{CC}$ & DD & $\mathrm{D}$ & $\mathrm{C}$ & DD \\
\hline Italy & $\mathrm{C}$ & $\mathrm{D}$ & $\mathrm{C}$ & $\mathrm{C}$ & $\mathrm{D}$ & $\mathrm{D}$ & $\mathrm{C}$ & $\mathrm{CC}$ & & $\mathrm{DD}$ & $\mathrm{C}$ & C & $\mathrm{DD}$ & $\mathrm{C}$ & $\mathrm{C}$ & D \\
\hline Luxembourg & $\mathrm{D}$ & $\mathrm{D}$ & $\mathrm{D}$ & $\mathrm{DD}$ & $\mathrm{D}$ & $\mathrm{DD}$ & $\mathrm{DD}$ & $\mathrm{C}$ & $\mathrm{DD}$ & & $\mathrm{D}$ & $\mathrm{D}$ & $\mathrm{DD}$ & $\mathrm{D}$ & $\mathrm{D}$ & $\mathrm{DD}$ \\
\hline Netherlands & $\mathrm{C}$ & $\mathrm{C}$ & $\mathrm{CC}$ & $\mathrm{C}$ & $\mathrm{D}$ & $\mathrm{D}$ & $\mathrm{CC}$ & $\mathrm{CC}$ & $\mathrm{C}$ & $\mathrm{D}$ & & D & $\mathrm{D}$ & $\mathrm{C}$ & $\mathrm{CC}$ & $\mathrm{D}$ \\
\hline Portugal & $\mathrm{D}$ & $\mathrm{C}$ & $\mathrm{C}$ & $\mathrm{C}$ & $\mathrm{D}$ & $\mathrm{D}$ & $\mathrm{C}$ & $\mathrm{CC}$ & $\mathrm{C}$ & $\mathrm{D}$ & $\mathrm{D}$ & & $\mathrm{DD}$ & $\mathrm{D}$ & $\mathrm{C}$ & DD \\
\hline $\begin{array}{l}\text { Slovak } \\
\text { Republic }\end{array}$ & $\mathrm{DD}$ & $\mathrm{DD}$ & $\mathrm{D}$ & DD & $\mathrm{DD}$ & $\mathrm{D}$ & $\mathrm{DD}$ & $\mathrm{DD}$ & $\mathrm{DD}$ & DD & $\mathrm{D}$ & $\mathrm{DD}$ & & $\mathrm{D}$ & $\mathrm{D}$ & $\mathrm{D}$ \\
\hline Slovenia & $\mathrm{C}$ & $\mathrm{D}$ & $\mathrm{CC}$ & $\mathrm{D}$ & $\mathrm{DD}$ & $\mathrm{D}$ & $\mathrm{D}$ & $\mathrm{D}$ & $\mathrm{C}$ & $\mathrm{D}$ & $\mathrm{C}$ & $\mathrm{D}$ & $\mathrm{D}$ & & $\mathrm{CC}$ & CC \\
\hline Spain & $\mathrm{C}$ & $\mathrm{CC}$ & $\mathrm{CC}$ & $\mathrm{CC}$ & $\mathrm{C}$ & $\mathrm{C}$ & $\mathrm{D}$ & $\mathrm{C}$ & $\mathrm{C}$ & $\mathrm{D}$ & $\mathrm{CC}$ & $\mathrm{C}$ & $\mathrm{D}$ & $\mathrm{CC}$ & & $\mathrm{DD}$ \\
\hline Poland & $\mathrm{D}$ & $\mathrm{D}$ & $\mathrm{DD}$ & $\mathrm{D}$ & $\mathrm{DD}$ & D & $\mathrm{DD}$ & DD & D & $\mathrm{DD}$ & $\mathrm{D}$ & $\mathrm{DD}$ & $\mathrm{D}$ & $\mathrm{CC}$ & DD & \\
\hline \multicolumn{17}{|c|}{$\begin{array}{l}\text { D: Bilateral sectoral dissimilarity higher in } 2008 \text { compared to } 2003, \Delta S \in(0 ; 5 \%) ; 41 \text { bilateral } \\
\text { comparisons }\end{array}$} \\
\hline \multicolumn{17}{|c|}{$\begin{array}{l}\text { DD: Bilateral sectoral dissimilarity higher in } 2008 \text { compared to } 2003 ; \Delta S \geq 5 \% ; 17 \text { bilateral } \\
\text { comparisons }\end{array}$} \\
\hline \multicolumn{17}{|c|}{$\begin{array}{l}\text { C: Bilateral sectoral dissimilarity lower in } 2008 \text { compared to 2003; } \Delta S \in(-5 \%, 0] ; 31 \text { bilateral } \\
\text { comparisons }\end{array}$} \\
\hline \multicolumn{17}{|c|}{$\begin{array}{l}\text { CC: Bilateral sectoral dissimilarity lower in } 2008 \text { compared to } 2003 ; \Delta S \leq-5 \% \text {; } 16 \text { bilateral } \\
\text { comparisons }\end{array}$} \\
\hline
\end{tabular}

S o u r c e : own calculations based on OECD data, GDP data (decomposition of Gross value added at basic prices, total activity, ISIC Rev 4 (10 industries breakdown).

The general divergence tendency across EMU countries is more pronounced in the subsequent 2008 vs. 2013 comparison, where 72 of 105 bilateral comparisons point to increasing sectoral dissimilarities, of which 38 are characterized by relatively strong divergence. The highest levels of divergence were observed in the countries worst hit by the global financial crisis, i.e. Greece, Ireland, Italy. Significant divergence was also observed in Slovenia and Estonia. In other words, highest divergence was recorded in EMU Southern economies (Greece, Italy and Portugal and Slovenia) which are highly dependent on tourism and in countries which recorded a significant decrease in GDP in the first phase of the global financial crisis, like Ireland and Estonia. Interestingly, the Netherlands and 
Belgium have also experienced large increases in bilateral sectoral divergence with the majority of examined member countries. Convergence was recorded in 33 cases, of which 8 exhibited relatively strong convergence. Only a few countries, i.e. Spain, Germany, France and the Slovak Republic, had as many as, or more, bilateral convergence than divergence comparisons over the 2008-2013 period. Overall, it is clear that divergence in economic structures has advanced over the last decade, with an especially strong effect after the outbreak of the global financial crisis of $2008+$.

TABLE 2. Bilateral sectoral dissimilarity index S (ij) - 2008 vs. 2013

\begin{tabular}{|c|c|c|c|c|c|c|c|c|c|c|c|c|c|c|c|c|}
\hline 2008-2013 & AUT & $\mathrm{BEL}$ & EST & FIN & FRA & DEU & GRC & IRL & ITA & LUX & NED & PRT & SVK & SVN & ESP & POL \\
\hline Austria & & $\mathrm{DD}$ & $\mathrm{C}$ & $\mathrm{D}$ & $\mathrm{C}$ & $\mathrm{C}$ & $\mathrm{DD}$ & $\mathrm{DD}$ & $\mathrm{D}$ & $\mathrm{D}$ & $\mathrm{DD}$ & $\mathrm{D}$ & $\mathrm{C}$ & D & $\mathrm{C}$ & DD \\
\hline Belgium & $\mathrm{DD}$ & & $\mathrm{DD}$ & $\mathrm{C}$ & $\mathrm{C}$ & D & $\mathrm{DD}$ & $\mathrm{DD}$ & D & $\mathrm{C}$ & D & $\mathrm{DD}$ & D & D & D & DD \\
\hline Estonia & $\mathrm{C}$ & $\mathrm{DD}$ & & $\mathrm{C}$ & $\mathrm{D}$ & $\mathrm{C}$ & $\mathrm{DD}$ & $\mathrm{DD}$ & $\mathrm{DD}$ & $\mathrm{DD}$ & $\mathrm{DD}$ & $\mathrm{DD}$ & $\mathrm{CC}$ & $\mathrm{DD}$ & $\mathrm{DD}$ & $\mathrm{C}$ \\
\hline Finland & $\mathrm{D}$ & $\mathrm{C}$ & $\mathrm{C}$ & & $\mathrm{CC}$ & DD & $\mathrm{D}$ & $\mathrm{DD}$ & $\mathrm{C}$ & $\mathrm{D}$ & $\mathrm{D}$ & $\mathrm{C}$ & $\mathrm{D}$ & $\mathrm{DD}$ & $\mathrm{CC}$ & DD \\
\hline France & $\mathrm{C}$ & $\mathrm{C}$ & $\mathrm{D}$ & $\mathrm{CC}$ & & $\mathrm{C}$ & $\mathrm{DD}$ & $\mathrm{DD}$ & $\mathrm{D}$ & $\mathrm{C}$ & $\mathrm{D}$ & $\mathrm{D}$ & $\mathrm{CC}$ & $\mathrm{C}$ & $\mathrm{CC}$ & $\mathrm{D}$ \\
\hline Germany & $\mathrm{C}$ & $\mathrm{D}$ & $\mathrm{C}$ & $\mathrm{DD}$ & $\mathrm{C}$ & & $\mathrm{DD}$ & $\mathrm{D}$ & $\mathrm{D}$ & $\mathrm{D}$ & $\mathrm{D}$ & $\mathrm{C}$ & $\mathrm{CC}$ & $\mathrm{CC}$ & $\mathrm{CC}$ & $\mathrm{D}$ \\
\hline Greece & $\mathrm{DD}$ & $\mathrm{DD}$ & $\mathrm{DD}$ & $\mathrm{D}$ & $\mathrm{DD}$ & $\mathrm{DD}$ & & $\mathrm{DD}$ & $\mathrm{DD}$ & $\mathrm{DD}$ & $\mathrm{DD}$ & $\mathrm{D}$ & $\mathrm{D}$ & DD & $\mathrm{C}$ & DD \\
\hline Ireland & $\mathrm{DD}$ & $\mathrm{DD}$ & $\mathrm{DD}$ & $\mathrm{DD}$ & $\mathrm{DD}$ & $\mathrm{D}$ & $\mathrm{DD}$ & & $\mathrm{DD}$ & $\mathrm{DD}$ & $\mathrm{DD}$ & $\mathrm{DD}$ & $\mathrm{D}$ & $\mathrm{DD}$ & $\mathrm{DD}$ & DD \\
\hline Italy & $\mathrm{D}$ & D & $\mathrm{DD}$ & $\mathrm{C}$ & D & $\mathrm{D}$ & $\mathrm{DD}$ & $\mathrm{DD}$ & & D & $\mathrm{DD}$ & $\mathrm{C}$ & $\mathrm{C}$ & D & $\mathrm{C}$ & DD \\
\hline Luxembourg & $\mathrm{D}$ & $\mathrm{C}$ & $\mathrm{DD}$ & $\mathrm{D}$ & $\mathrm{C}$ & $\mathrm{D}$ & $\mathrm{DD}$ & $\mathrm{DD}$ & $\mathrm{D}$ & & $\mathrm{D}$ & $\mathrm{DD}$ & $\mathrm{C}$ & $\mathrm{D}$ & $\mathrm{DD}$ & $\mathrm{DD}$ \\
\hline Netherlands & $\mathrm{DD}$ & $\mathrm{D}$ & $\mathrm{DD}$ & $\mathrm{D}$ & $\mathrm{D}$ & $\mathrm{D}$ & $\mathrm{DD}$ & $\mathrm{DD}$ & $\mathrm{DD}$ & $\mathrm{D}$ & & $\mathrm{DD}$ & $\mathrm{C}$ & $\mathrm{D}$ & $\mathrm{DD}$ & DD \\
\hline Portugal & $\mathrm{D}$ & $\mathrm{DD}$ & $\mathrm{DD}$ & $\mathrm{C}$ & $\mathrm{D}$ & $\mathrm{C}$ & $\mathrm{D}$ & $\mathrm{DD}$ & $\mathrm{C}$ & $\mathrm{DD}$ & $\mathrm{DD}$ & & $\mathrm{C}$ & $\mathrm{D}$ & $\mathrm{C}$ & $\mathrm{D}$ \\
\hline & $\mathrm{C}$ & $\mathrm{D}$ & $\mathrm{CC}$ & $\mathrm{D}$ & $\mathrm{CC}$ & $\mathrm{CC}$ & $\mathrm{D}$ & $\mathrm{D}$ & C & $\mathrm{C}$ & $\mathrm{C}$ & C & & $\mathrm{D}$ & $\mathrm{C}$ & $\mathrm{C}$ \\
\hline Slovenia & D & D & DD & $\mathrm{DD}$ & $\mathrm{C}$ & CC & $\mathrm{DD}$ & DD & $\mathrm{D}$ & $\mathrm{D}$ & $\mathrm{D}$ & $\mathrm{D}$ & $\mathrm{D}$ & & D & DD \\
\hline Spain & $\mathrm{C}$ & $\mathrm{D}$ & DD & $\mathrm{CC}$ & $\mathrm{CC}$ & $\mathrm{CC}$ & $\mathrm{C}$ & $\mathrm{DD}$ & $\mathrm{C}$ & $\mathrm{DD}$ & $\mathrm{DD}$ & $\mathrm{C}$ & $\mathrm{C}$ & $\mathrm{D}$ & & $\mathrm{D}$ \\
\hline Poland & $\mathrm{DD}$ & $\mathrm{DD}$ & $\mathrm{C}$ & $\mathrm{DD}$ & $\mathrm{D}$ & $\mathrm{D}$ & $\mathrm{DD}$ & $\mathrm{DD}$ & $\mathrm{DD}$ & $\mathrm{DD}$ & $\mathrm{DD}$ & $\mathrm{D}$ & $\mathrm{C}$ & $\mathrm{DD}$ & D & \\
\hline \multicolumn{17}{|c|}{$\begin{array}{l}\text { D: Bilateral sectoral dissimilarity higher in } 2008 \text { compared to 2003, } \Delta S \in(0 ; 5 \%) ; 34 \text { bilateral } \\
\text { comparisons }\end{array}$} \\
\hline \multicolumn{17}{|c|}{$\begin{array}{l}\text { DD: Bilateral sectoral dissimilarity higher in } 2008 \text { compared to } 2003 ; \Delta S \geq 5 \% \text {; } 38 \text { bilateral } \\
\text { comparisons }\end{array}$} \\
\hline \multicolumn{17}{|c|}{$\begin{array}{l}\text { C: Bilateral sectoral dissimilarity lower in } 2008 \text { compared to 2003; } \Delta S \in(-5 \%, 0] ; 25 \text { bilateral } \\
\text { comparisons }\end{array}$} \\
\hline \multicolumn{17}{|c|}{$\begin{array}{l}\text { CC: Bilateral sectoral dissimilarity lower in } 2008 \text { compared to } 2003 ; \Delta S \leq-5 \% \text {; } 8 \text { bilateral } \\
\text { comparisons }\end{array}$} \\
\hline
\end{tabular}

S o u r c e : own calculations based on OECD data, GDP data (decomposition of Gross value added at basic prices, total activity, ISIC Rev 4 (10 industries breakdown). 
Bilateral comparisons from both the 2003-2008 and 2008-2013 periods show that Poland has diverged in economic structures from almost all EMU countries. Interestingly, significant structural divergence has been of roughly the same magnitude in the case of Poland between 2003 and 2008, as well as between 2008 and 2013. This observation suggests that Poland has become a less suitable member for the EMU in terms of sectoral similarity over the last decade, as measured by the Krugman's sectoral dissimilarity index.

The global shock of 2008 had a pronounced asymmetric impact on the EMU economies. Asymmetric responses of countries to the global crisis have apparently further augmented sectoral dissimilarity, leading to even more divergence in the 2008-2013 period. These asymmetric responses took place i.a. in regional labor markets and national productivity levels. The analysis of productivity and labor market structures is important in the context of divergence since both factors determine regional economic performance and allow regions to adjust to occurring shocks.

Three particularly important tendencies have been documented in this respect in the most recent study by Beck and Grodzicki [2014, pp. 53-55], which includes a comprehensive analysis of labor productivity changes in the EU 27 countries over the period of 1996-2010. First, a general convergence tendency in relative productivity levels across the EU 27 countries has not been observed so far. Second, 'Southern' Eurozone members, including Italy and Spain, recorded a drop in relative productivity over the subject time horizon. Specifically, in 1996 they belonged to the group of countries with the highest productivity levels in the EU, together with Belgium, France and the Netherlands. In 2010 they joined the group of Western European countries (Germany, UK, Sweden and Austria) with relatively lower levels of productivity. Third, Poland has recorded a considerable increase in relative productivity over this period, approaching the productivity levels of Portugal and Hungary in 2010.

In line with these findings, Fingleton et al. [2014, pp. 10-14, 32-34] also documented growing discrepancies in productivity and employment between 'Northern' and 'Southern' Eurozone states from the onset of the EMU until 2011. In particular, they found that the productivity gap between 'Northern' and 'Southern' EMU members has steadily increased over the last decade. Interestingly enough, this tendency has not visibly changed in any direction after the outbreak of the global financial crisis.

Similar differences and tendencies between 'Northern', 'Southern', and 'Eastern' countries can also be observed in terms of competitiveness and national income levels (see table 3). While 'Northern' EMU countries exhibit relatively high competitiveness and national income levels, the 'Eastern' (CEE) countries have continued to exhibit, in relative terms, the lowest levels, and they intensively catch up with the EU28 averages.

We note that the observed convergence of GNI per capita at PPP of CEE countries to the $\mathrm{EU}$ mean does not result from the adoption of a common currency in these economies. Rather, it is a consequence of the catching-up process taking place in CEE economies, with initially low levels of economic development that gradually converge with GNI per capita 
levels of developed economies. Interestingly, this catching-up process of CEE economies has not been halted by the outbreak of the global financial crisis. As for 'Southern' EMU economies, they recorded average but declining levels of competitiveness and national income in recent years. Importantly, the three tendencies in the development of relative national income levels that are characteristic to each group of countries are expected to persist in the near future [Molle, 2014, pp. 40-46].

\section{TABLE 3. Relative GNI per capita at PPP (EU28 as benchmark)}

\begin{tabular}{|l|r|r|r|r|c|}
\hline \multicolumn{1}{|c|}{ regionlyear } & 2000 & 2007 & 2013 & ${ }^{*} 2020$ & population in 2013 \\
\hline Northern EMU countries & $122 \%$ & $117 \%$ & $118 \%$ & ${ }^{*} 115 \%$ & $38.2 \%$ \\
\hline Southern EMU countries & $104 \%$ & $100 \%$ & $93 \%$ & $90 \%$ & $25.6 \%$ \\
\hline Eastern countries & $44 \%$ & $54 \%$ & $63 \%$ & ${ }^{*} 72 \%$ & $20.6 \%$ \\
\hline EU28 & $100 \%$ & $100 \%$ & $100 \%$ & $100 \%$ & $100 \%$ \\
\hline
\end{tabular}

* 2020 forecasts of GDP per capita at PPP from Molle [2014, p. 44].

** Groups of countries presented in Molle [2014, p. 44] differ in comparison with this division (North (EU), South (EU) East and V4 considered in the study). Forecasts are presented to present the general tendency expected.

Northern EMU: Austria, Belgium, Finland, France, Germany, Ireland, Netherlands, Luxembourg; Southern EMU: Cyprus, Malta, Greece, Portugal, Spain, Italy; Eastern countries: Bulgaria, Croatia, Czech Republic, Estonia, Hungary, Latvia, Lithuania, Poland, Romania, Slovenia, Slovakia.

S o u r c e: The World Bank, GNI PPP in USD and population data.

Divergence tendencies between the three groups, in this respect, had been observed prior to 2008. The outbreak of the global financial crisis aggravated some of these tendencies, and the three groups of economies have reacted in different ways to that crisis. While 'Northern' EMU and CEE countries accommodated the consequences of the global financial crisis and CEE countries continued to grow after 2009, 'Southern' EMU economies still struggle with the consequences of the $2008+$ crisis. As a result, their relative competitiveness declined and the average standard of living has decreased [Molle, 2014, pp. 43].

Last but not least, as to the labor market structure, Beck and Grodzicki [2014, pp. 105123] estimated that the share of individual sectors in employment has not significantly changed over the 1996-2010 period in EU countries. Although the percentage of employed has gradually increased in the service sector (especially in the financial services and non-market services) at the expense of agriculture and industry, convergence in sectoral similarity of labor markets has been slow and inconsiderable.

For business cycle convergence within the euro area, we use the Hodrick - Prescott-filter to extract the cyclical component from Eurozone countries' GDP series. This approach has been suggested by Frankel and Rose [1996, p. 11-14], as one of many quantitative techniques for measuring business cycle synchronization [Konopczak, 2010, pp. 99-128].

To assess the strength of convergence or divergence tendencies between EMU countries, bilateral cross-correlations of economic cycles of EMU states are compared in Table 4. 
Cross-correlations of countries' cyclical GDP components are extracted from GDP y-o-y dynamics. The cyclical component of the GDP series is obtained through the Hodrick - Prescott-filter decomposition [Hodrick and Prescott, 1997].

$$
\min _{\left\{g_{t}\right\}_{t=-1}^{T}}\left(\sum_{t=1}^{T}\left(y_{t}-g_{t}\right)^{2}+\lambda \sum_{t=1}^{T}\left[\left(g_{t}-g_{t-1}\right)-\left(g_{t-1}-g_{t-2}\right)\right]^{2}\right)
$$

where $y_{t}$ is the 4-th difference of the logs of quarterly GDP level series. The smoothing parameter $\lambda$ has the value of 1600 , as suggested for quarterly data, $g_{t}$ is the trend component (solution to the minimization problem). The cyclical component is denoted by $\left(y_{t}-g_{t}\right)$.

Our comparison is made for two periods, prior to the outbreak of the global crisis, i.e. 2003-2007, and after that outbreak, i.e. 2010-2014. Importantly, data for the 2008-2009 interval, when the global financial crisis had the most pronounced impact on EMU economies, has been excluded from computations due to its undesired significant symmetric impact (a symmetric abrupt decline and subsequent symmetric rebound) on the GDP growth of all EMU countries. ${ }^{18}$ Precisely speaking, correlation coefficients from the period of 2003-2007 are compared with those from the period of 2010-2014. Where bilateral correlation increased between the two periods, then the bilateral comparison is marked as 'pos', indicating growing correlation of business cycles; otherwise it is 'neg'.

The business cycle correlation results presented in Table 4 point to the existence of considerable overall divergence in business cycle similarity (real divergence) among the EMU countries over the last decade. In particular, 96 out of 120 bilateral comparisons for the 2003-2014 period are characterized by a growing divergence in business cycles, and, no EMU country has recorded growing business cycle correlation in more bilateral comparisons than it has recorded increased business cycle divergence. Belgium and Luxembourg had the most 'positive' bilateral comparisons. Conversely, Greece, Ireland, Latvia, Portugal, Slovakia, Slovenia, and Spain have recorded all (or all but one) 'negative' bilateral comparisons with examined countries, meaning that their business cycles diverged from all but one economy (-ies). The most significant and likely cause for this tendency is the impact of the global financial crisis on EMU economies.

In fact, the above-described effect of real divergence in business cycles over the 2003-2014 period may be a consequence of more unfavorable real divergence tendencies prevalent in the EMU. The outbreak of the global financial crisis has led to further divergence of economic structures, regional productivities, and significant changes on national labor markets. Equally important, the global financial crisis has also reduced the potential of mechanisms to smooth asymmetric shocks in the Eurozone, i.a. it has aggravated differences in fiscal conditions among member states and brought about a deterioration of the banking sector's financial stance.

Poland exhibited cyclical convergence with EMU's largest economies, Germany, France and Italy. These countries are also Poland's largest trading partners in the Eurozone. 
Increased cyclical correlation with Germany is i.a. due to strong trade ties between these countries. Germany is Poland's largest trading partner, accounting for 23.4 percent of Poland's total trade (imports and exports) in 2013 [Ministerstwo Gospodarki, 2014, pp. 31-34]. At the same time, the Polish economy diverged from relatively smaller and/or geographically distant economies, some of which have been considerably affected by the global financial crisis, i.a. Spain and Ireland. On the whole, the Polish economy's business cycles were characterized by increased synchronization with the core EMU countries for the period of 2003-2014, which is a positive tendency in the light of Poland's future accession to the Eurozone.

TABLE 4. Change of correlation between cyclical components of y-o-y GDP dynamics (HP-filtered), 2003-2007 and 2010-2014

\begin{tabular}{|c|c|c|c|c|c|c|c|c|c|c|c|c|c|c|c|c|c|}
\hline & AUT & $\mathrm{BEL}$ & EST & FIN & FRA & $\mathrm{DEU}$ & GRC & IRL & ITA & LVA & LUX & NED & PRT & SVK & SVN & ESP & POL \\
\hline Austria & & neg & pos & neg & neg & neg & neg & neg & neg & neg & pos & neg & neg & neg & neg & neg & neg \\
\hline Belgium & neg & & neg & pos & pos & pos & neg & neg & pos & neg & pos & pos & neg & neg & neg & neg & pos \\
\hline Estonia & pos & neg & & pos & neg & neg & neg & neg & neg & neg & neg & neg & neg & neg & neg & neg & neg \\
\hline Finland & neg & pos & pos & & neg & pos & neg & neg & neg & neg & pos & pos & neg & neg & neg & neg & neg \\
\hline France & neg & pos & neg & neg & & pos & neg & neg & pos & neg & pos & pos & neg & neg & neg & neg & pos \\
\hline Germany & neg & pos & neg & pos & pos & & neg & neg & pos & neg & pos & neg & neg & neg & neg & neg & pos \\
\hline Greece & neg & neg & neg & neg & neg & neg & & neg & neg & neg & neg & neg & neg & neg & neg & neg & pos \\
\hline Ireland & neg & neg & neg & neg & neg & neg & neg & & neg & neg & neg & neg & neg & pos & neg & neg & neg \\
\hline Italy & neg & pos & neg & neg & pos & pos & neg & neg & & neg & pos & pos & neg & neg & neg & pos & pos \\
\hline Latvia & neg & neg & neg & neg & neg & neg & neg & neg & neg & & neg & neg & neg & neg & neg & neg & neg \\
\hline Luxembourg & pos & pos & neg & pos & pos & pos & neg & neg & pos & neg & & pos & neg & neg & neg & neg & pos \\
\hline Netherlands & neg & pos & neg & pos & pos & neg & neg & neg & pos & neg & pos & & neg & neg & neg & neg & pos \\
\hline Portugal & neg & neg & neg & neg & neg & neg & neg & neg & neg & neg & neg & neg & & neg & neg & neg & pos \\
\hline Slovakia & neg & neg & neg & neg & neg & neg & neg & pos & neg & neg & neg & neg & neg & & neg & neg & neg \\
\hline Slovenia & neg & neg & neg & neg & neg & neg & neg & neg & neg & neg & neg & neg & neg & neg & & pos & neg \\
\hline Spain & neg & neg & neg & neg & neg & neg & neg & neg & pos & neg & neg & neg & neg & neg & pos & & neg \\
\hline Poland & neg & pos & neg & neg & pos & pos & Pos & neg & pos & neg & pos & pos & pos & neg & neg & neg & \\
\hline
\end{tabular}

Notes: Quarterly GDP data, not seasonally adjusted, current prices.

S o u r c e : own calculations based on Eurostat data.

To conclude the analysis presented in this section, we point to an interesting trend taking place in intra- and extra-EMU trade that may impact future real convergence between Eurozone countries. The endogeneity theory of OCA suggests that currency unification 
should amplify intra-industry trade within the EMU, and thus lead to greater synchronization of business cycles between currency union members. The discussion about the EMU's effect on trade presented in the previous section indicates that the realized effect of the euro on trade creation is much smaller than Frankel and Rose [2000] suggested. Among others reasons, the effect may be small because Eurozone members exhibited a significant level of mutual economic integration prior to currency unification. Therefore, a substantial part of the trade creation effect may have already been realized in prior years. If so, the common EMU market may also show signs of succeeding saturation resulting from the high proliferation of domestic (EMU) products, and possibly greater dynamics of trade creation with non-EMU countries than the dynamics of intra-EMU trade.

Figure 2 presents the development of intra- (trade between EA-17 Member States) and extra-EMU (trade between Member States and non-member countries) trade volume for the 2003-2014 period. Specifically, Figure 2 depicts the development of intra-EA17 (Eurozone of 17 countries) trade volume over the last decade. This volume is juxtaposed with extra-EA17 trade volume, i.e. trade between EA17 countries and the rest of the world. Average monthly values for a given year are chosen as units.

\section{FIGURE 2. Intra-EMU (EA-17) and Extra-EMU trade values}

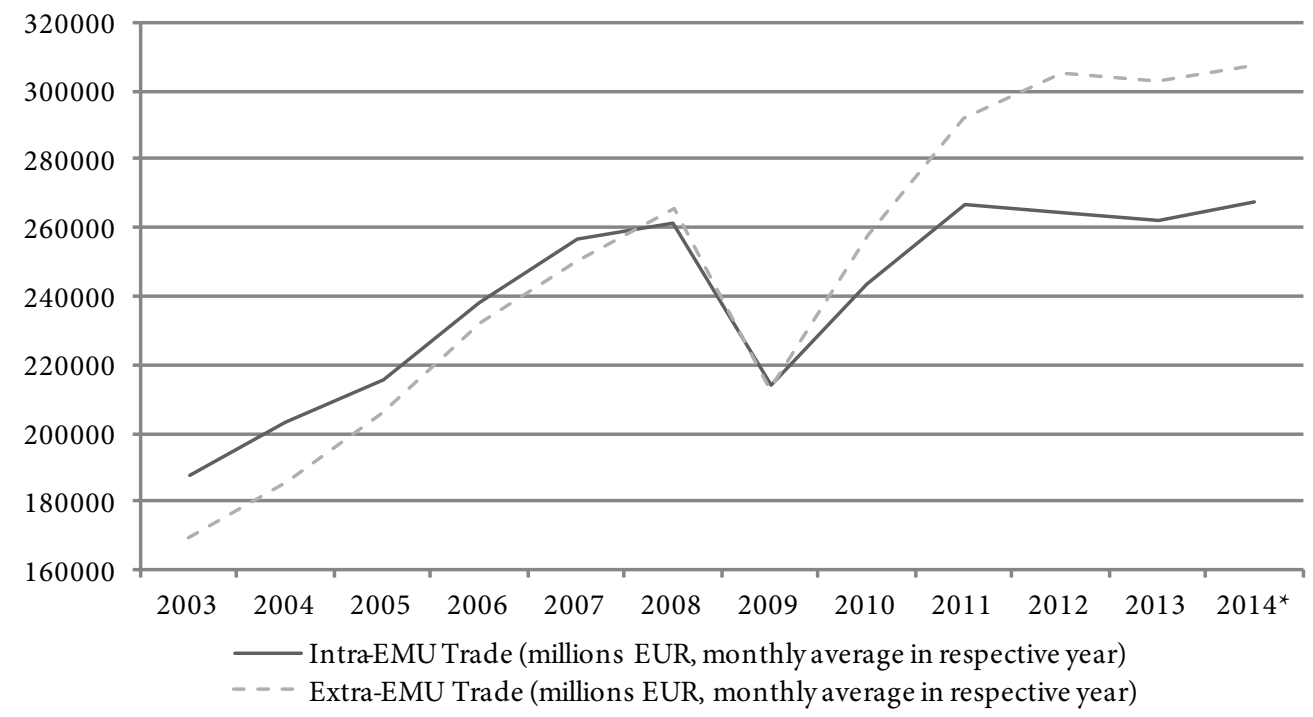

Notes: *average of the first 11 months; December 2014 data not available.

S o u r c e: Eurostat data on intra- and extra-EA17 trade. Extra-EMU (EA-17) trade statistics cover the trading of goods between member states and non-member countries. Intra-EMU trade statistics cover the trading of goods between member states. 
These data suggest two important considerations. First, intra-EA17 trade increased until 2008 but its increment has been significantly surpassed by the growth of the extra-EA17 trade. Second, both trade volumes increased steadily until the outbreak of the financial crisis in the EMU, i.e. from the beginning of the Greek crisis. Both volumes rebounded in 2010 to pre-crisis levels, however, while intra-EA17 trade volume remained on the same level afterwards, while the extra-EA17 trade volume further augmented.

This is an intriguing observation, insofar as the global financial crisis originated outside the EMU, while intra-EMU (and not extra-EMU) trade has been the most affected by this external shock. Moreover, intra-EMU trade has rebounded after 2010, and extra-EMU trade increased further after 2009, despite significant appreciation of the euro in 2009-2010.

On average, extra-EMU trade increased substantially more over the last decade than the intra-EMU trade did. This observed discrepancy between growth rates of intra- and extra-EMU trade volumes may stem i.a. from the fact that due to the general advance in technology, trade between distant countries has become less constrained. Extra-EMU trade is increasing faster because entering new markets does not require an intensification of intra-industry trade for its augmentation; access to new foreign markets is sufficient. Global specialization in production patterns also enforces greater trade among countries, resulting in greater bilateral trade between countries.

On the other hand, the euro area market may already be exhibiting signs of saturation concerning domestically manufactured products. As a result, the pace of growth of intraEMU trade will diminish over time as market saturation levels increase. Interestingly, the outbreak of the crisis has apparently halted the growth of intra-EMU trade, which only regained its pre-crisis level after 2011, remaining roughly at the same level afterwards. Before the start of the crisis FDI flows enhanced the growth of intra-EMU trade. However, the financial crisis halted FDI flows, which has surely contributed to stagnation in intra-EMU trade volume after 2010. The future evolution of intra-EMU trade will verify whether divergence in intra- and extra-EMU trade volume growth rates is a temporary phenomenon or a long-term trend.

\section{Concluding Remarks}

Considerations over real divergence and convergence tendencies in the EMU and the unspecified size of the endogeneity effect of monetary unification on trade lead to a question: will the Eurozone become more suitable over time, or is it self-defeating due to rising asymmetries between its economies? If endogeneity prevails over various geographical and sectoral centralization and divergence tendencies, then the EMU will gradually become an optimal currency area at some point in the future (expost unification), despite the fact that it is not at present and was not prior to (exante) its creation. 
Our analysis of the EMU accession's effect on trade shows that the realized effect of the euro on trade creation is much smaller than Frankel and Rose [2000] suggested. Among other reasons, that effect may be smaller because Eurozone members exhibited a significant level of mutual economic integration prior to currency unification. Also, Frankel and Rose's [2000] results included countries that have been part of pegged currency regimes, and not formal members of monetary unions (due to data availability), and considered countries that are not representative of EMU countries in terms of size, level of economic development and geographic proximity.

Because the endogenity effect in the Eurozone is much smaller than suggested by Frankel and Rose, divergence tendencies in the EMU have become increasingly visible and intense over time, creating strains that threatening the Eurozone stability. Indeed, we presume that the common EMU may already be showing signs of progressive saturation from the high proliferation of domestic products. Greater dynamics of trade creation with non-EMU countries than are observed concerning intra-EMU trade, specifically, the weak positive trend post- 2008 crisis, is a likely indicator of this tendency.

What is most important to the efficient functioning of the Eurozone in the long-run is a sufficient level of real economic convergence between member states. This guarantees that economic shocks impacting the EMU have a symmetric, rather than an asymmetric, effect on members, requiring less adjustment from economic mechanisms to smooth adverse effects. Four selected real convergence criteria are analyzed in greater detail in this paper on the basis of most recent data (2003-2014) and research results from similar studies.

First, estimates of pairwise-Krugman's specialization index for the 2003-2013 period point to increasing dissimilarities in economic structures between selected EMU members. Divergence in economic structures has advanced over the last decade in the Eurozone, especially after the outbreak of the global financial crisis, and the Polish economy seems to follow this trend. It has become a less suitable member for the EMU in terms of sectoral similarity over the last decade.

Second, the most recent economic studies [Fingleton et al., 2014; Beck and Grodzicki, 2014] suggest that no general convergence tendency was observed in relative productivity levels across EU 27. In fact, discrepancies in productivity and employment between Northern and Southern Eurozone states are observed from the onset of the EMU.

Finally, business cycle correlation results for the 2003-2014 period suggest a divergence trend in business cycle similarity among Eurozone countries. The Polish economy, however, recorded cyclical convergence with its largest trading partners, who are also the EMU's largest economies (Germany, France and Italy). Increased cyclical correlation with Germany is i.a. due to especially strong trade ties between these countries.

To conclude, the increasing sectoral dissimilarity, growing productivity gap between 'groups' of EMU countries and increased business cycle divergence show that divergence tendencies are visible in the Eurozone. This matters, because the effective long-run functioning of any country in the EMU largely depends on its ability to maintain relative 
competitiveness within the union. Special attention should therefore be directed to the Polish economy's ability to meet real convergence criteria before its accession to the EMU, so as to enhance that country's ability to function smoothly in the Eurozone.

More generally, our results support the 'Krugman's scenario' as accurately describing the current state of the EMU. Many of the observed divergence tendencies were reinforced by the global financial crisis and will likely persist, at least in the near future, calling for reforms and the adaptation of new policies within the EMU. We will soon know whether divergence tendencies reinforced by the global financial crisis will revert into convergence in the EMU.

\section{Notes}

1 Henryk Bąk, corresponding author: henryk.bak@sgh.waw.pl

2 Sebastian Maciejewski, Warsaw School of Economics, University of Mannheim and Free University of Amsterdam's graduate, sebastian.michal.maciejewski@gmail.com

3 A (single) currency area refers to a geographical entity where one single currency is used as means of payment, and there exist one central bank that determines its monetary policy. Theoretically, a currency area can also have more than one currency, but it is important that all exchange rates be invariably fixed with each other, so that each currency is fully convertible [Vaubel, 1988, pp. 223-228]. The second definition will not be further considered. The term 'optimal' refers to the size of a currency area and the efficiency of economic mechanisms that smooth arising shocks within the area restoring internal and external domestic balances.

4 Asymmetric or state-specific shocks are defined as demand or supply shocks that affect a specific region or regions within the monetary union. Supply shocks spring from i.e. wage or raw-materials price changes, as well as fiscal and common monetary policy. Demand shocks may ensue due to i.e. shifts in investment and demand, preferences, and macroeconomic or fiscal policy changes.

5 As is often the case in the economic literature, the words 'sectoral' and 'industrial' will be used interchangeably in this paper in the context of discussing similarity in economic structures, convergence in economic structures and Krugman's similarity index.

6 The degree of openness is considered in terms of a country's exports and imports with respect to its GDP.

7 These are presented in the second part of this paragraph. Decentralization externalities result from i.a. congestion, infrastructure shortage, pollution, high labor, real estate or regulation costs, shortages of skilled labor, and communication technology growth [HM Treasury, 2003b].

8 One should bear in mind that the outflow will be constrained by sunk costs.

9 Intra-industry trade is decomposed into horizontal and vertical intra-industry trade. Horizontal trade is characterized by exchanges of similar products with differentiated varieties. Vertical trade is characterized by exchanges of similar goods that differ in e.g. quality or price.

10 In particular, multinational companies decide more frequently than before to divide their production processes into processing phases located in different regions and countries. As these regions specialize in manufacturing sub-components used in further phases of the production process within a given company, they become vulnerable to decisions of multinational companies to change subcontractors due 
to e.g. cost-cutting reasons. With increased competition, it is likely that multinational companies may more frequently generate asymmetric shocks between regions or countries changing their subcontractors [Barczyk et al., 2010, pp. 67-69].

11 These costs are, among others, hedging and costs of gathering information regarding future exchange rates and prices.

12 The intensification of intra-industry trade is characteristic to currency unions consisting of developed economies, thus the EMU [Commission of the European Communities, 1990, pp. 220-232].

13 Results based on research on the trading activities of Belgian firms.

14 For more details, see [Nitsch and Pisu, 2008, pp. 15-19].

15 Slovakia and Slovenia are relatively open economies highly dependent on foreign capital and foreign technology. The significance of human capital, foreign technology and innovation on propensity to export is characteristic for these two economies; however, these effects may not necessarily be representative of all NMS.

16 The effect amounts to an approximately 0.33 percent increase in national income for every one percent increase in openness over 20 years.

17 Malta and Cyprus were not included in the comparison due to the relatively small size of their economies.

18 Particularly, this effect can be seen when results from the 2003-2008 and 2010-2014 comparison are juxtaposed with e.g. the results obtained from the 2005-2009 and 2010-2014 comparisons. In the latter case, only 3 bilateral comparisons show increased business cycle synchronization between the two periods, and 117 show a declining correlation of business cycles.

\section{References}

Asdrubali, P., Sørensen, B.E., Yosha, O. (1996), Channels of Interstate Risk Sharing: United States 1963-1990, Quarterly Journal of Economics, 111, pp. 1081-1110.

Barczyk, R., Lubiński, M., Konopczak, K., Marczewski, K. (2010), Synchronizacja wahań koniunkturalnych. Mechanizmy i konsekwencje, Wydawnictwo Uniwersytetu Ekonomicznego w Poznaniu, Poznań.

Barro, R., Tenreyro, S. (2007), Economic Effects of Currency Unions, Economic Enquiry, Vol. 45, No. 1, pp. 1-23. Baldwin, R., Di Nino, V., Fontagné, L., De Santis, R.A., Taglioni, D. (2008), Study on the Impact of the Euro on Trade and Foreign Direct Investment, European Economy, Economic Papers, 321, May 2008.

Bayoumi, T., Eichengreen, B. (1992), Shocking Aspects of European Monetary Integration, in: F. Torres, F. Giavazzi (eds.), Adjustment and Growth in the European Monetary Union, Cambridge University Press, CEPR.

Bąk, H. (2008), Interpretacja kryteriów konwergencji, in: J. Ostaszewski (ed.), Polska w strefie euro. Szanse i zagrożenia, Oficyna Wydawnicza SGH, Warszawa.

Bąk, H. (2015), Selected Problems of the Eurozone's Functioning - Conclusions for Poland, in: G. Wojtkowska-Łodej, H. Bąk (eds.), Selected Aspects of the Functioning of Poland in the European Union. The Balance of Ten Years of Membership, Warsaw School of Economics, Warsaw.

Beck, K. (2013), Determinants of Business Cycles Synchronization in the European Union and the Euro Area, Quarterly Journal of Economics and Economic Policy, Vol. 8, No. 4, pp. 25-48.

Beck, K., Grodzicki, M. (2014), Konwergencja realna i synchronizacja cykli koniunkturalnych w Unii Europejskiej, Wymiar strukturalny, Wydawnictwo Naukowe SCHOLAR, Warszawa.

Blanchard, O.J., Katz, L.F., Hall, R.E., Eichengreen, B. (1992), Regional Evolutions, Brookings Papers on Economic Activity, Vol. 1992, No. 1, pp. 1-75. 
Brzoza-Brzezina, M., Makarski, K., Wesołowski, G. (2012), Would it have paid to be in the Eurozone?, National Bank of Poland Working Paper, No. 128.

Cieślik, A., Michałek, J., Mycielski, J. (2012), Consequences of the euro adoption by Central and Eastern European (CEE) countries for their trade flows, National Bank of Poland Working Paper, No. 118.

Cieślik, A., Michałek, J., Mycielski, J. (2014b), Trade effects of the euro adoption by the EU new member states, Bank i Kredyt, No. 45(4), pp. 331-348.

Cieślik, A., Michałek, J., Michałek, A. (2014a), Does the Common Currency Increase Exports? Evidence from Firm-Level Data, International Journal of Management and Economics, No. 41, pp. 8-22.

Commission of the European Communities (1990), One market, one money. An evaluation of the potential benefits and costs of forming an economic and monetary union, European Economy No. 44.

Czarny, E., Folfas, P., Śledziewska K., Witkowski, B. (2013), Wpływ integracji monetarnej na wymianę towarową w warunkach kryzysu gospodarczego, Materiały i Studia, Zeszyt 300, NBP, Warszawa.

De Grauwe, P. (2014), Economics of Monetary Union, $10^{\text {th }}$ ed., Oxford University Press.

De Grauwe, P., Mongelli, F.P. (2005), Endogenities of Optimal Currency Areas. What Brings Countries Sharing a Single Currency Closer Together?, ECB Working Paper Series, No. 468.

Duchnowska, E. (2014), Polityka cenowa firm na rynkach zagranicznych - wyniki badań ankietowych, in: K. Marczewski (ed.), Ceny w handlu zagranicznym Polski, aspekty makro- i mikroekonomiczne, ELIPSA, Warszawa. Eichengreen, B. (1997), One Money for Europe? Lessons from the U.S. Currency Union, in: B. Eichengreen, European Monetary Unification: Theory, Practice and Analysis, Hong Kong, MIT Press, pp. 13-51.

Eichengreen B., von Hagen J. (1996), Fiscal Policy and the Monetary Union: Is There a Tradeoff between Federalism and Budgetary Restrictions?, NBER Working Paper, No. 5517.

Fingleton, B., Garretsen, H., Martin, R. (2014), Shocking Aspects of Monetary Union: The Vulnerability of Regions in Euroland, paper in preparation for the special issue of Journal of Economic Geography on the Future of Europe, 2 April, 2014.

Frankel, J.A., Rose, A.K. (1996), The Endogeneity of the Optimum Currency Area Criteria, NBER Working Paper Series, No. 5700.

Frankel, J.A., Rose, A.K. (1997), Is EMU more justifiable ex post than ex ante?, European Economic Review, 41, pp. 753-760.

Frankel, J.A., Rose, A.K. (2000), Estimating the Effect of Currency Unions on Trade and Output,NBER Working Paper Series, No. 7857.

Frankel, J.A. (2010), The Estimated Effects of the Euro on Trade: Why are They Below Historical Evidence on Effects of Monetary Unions Among Smaller Countries?, in:A. Alesina, F. Giavazzi (eds.), Europe and the Euro, University of Chicago Press.

HM Treasury (2003a), The United States as a Monetary Union, HM Treasury, London.

HM Treasury (2003b), The Location of Financial Activity and the Euro, HM Treasury, London.

HM Treasury (2003c), Submissions on EMU from leading academics, HM Treasury, London.

Hodrick, R.J., Prescott, E.C. (1997), Postwar U.S. Business Cycles: An Empirical Investigation, Journal of Money, Credit and Banking, Vol. 29, No. 1.

Kalemli-Ozcan, S., Sørensen, B.E., Yosha, O. (2004), Asymmetric Shocks and Risk Sharing in a Monetary Union: Updated Evidence and Policy Implications for Europe, CEPR Working Paper, No. 4463.

Kalemli-Ozcan, S., Sørensen, B.E., Yosha, O. (1999), Risk Sharing and Industrial Specialization: Regional and International Evidence, CEPR Working Paper, No. 2295.

Kenen, P.B. (1969), The Theory of Optimum Currency Areas: An Eclectic View, in: R.A. Swoboda, Monetary Problems of the International Economy, University of Chicago Press, pp. 41-60. 
Konopczak, K. (2010), Metody ilościowe badania synchronizacji cykli koniunkturalnych, in: Barczyk, R., Konopczak, K., Lubiński, M., Marczewski, K. (eds.), Synchronizacja wahań koniunkturalnych, mechanizmy $i$ konsekwencje, Wydawnictwo Uniwersytetu Ekonomicznego w Poznaniu, Poznań.

Konopczak, K. Marczewski, K. (2011), Why so different from other CEECs - Poland's cyclical divergence from the euro area during the recent financial crisis, Bank $i$ Kredyt, 42(2), pp. 7-30.

Krugman, P. (1991), Increasing Returns and Economic Geography, The Journal of Political Economy, Vol. 99, No. 3, pp. 483-499.

Krugman, P. (1993), Lessons from Massachusetts for EMU in: F. Torres, F. Giavazzi, Adjustment and Growth in the European Monetary Union, Cambridge University Press, pp. 241-261.

Krugman, P., Venables, A. (1993), Integration, Specialization and Adjustment, NBER Working Paper Series, No. 4559. Lubiński, M. (2010), Przyczyny i mechanizmy synchronizacji wahań koniunkturalnych, in: Barczyk, R., Konopczak, K., Lubiński, M., Marczewski, K. (eds.), Synchronizacja wahań koniunkturalnych, mechanizmy i konsekwencje, Wydawnictwo Uniwersytetu Ekonomicznego w Poznaniu, Poznań.

Marciniak, Z. (2010), Dwie fazy kryzysu finansowego i perspektywy, in: Wyzwania dla gospodarki polskiej w dobie kryzysu, Instytut Handlu Zagranicznego i Studiów Europejskich, Warsaw School of Economics, Warszawa.

Marczewski, K. (2010), Postępy w konwergencji realnej polskiej gospodarki - mierniki i determinanty, Polityka Gospodarcza, No. 19-20, pp. 9-29.

Marinheiro, C.F. (2003), Output Smoothing in EMU and OECD: Can We Forego Government Contribution? A Risk Sharing Approach, CESifo Working Paper, No. 1051.

McKinnon, R.I. (1963), Optimum Currency Areas, The American Economic Review, Vol. 53, No. 4, pp. 717-725.

McKinnon, R.I. (2008), Optimum Currency Areas: Mundell 1(1961) versus Mundell II (1973), at the Common Currency and its Future: Lessons for the New Member States Conference, NBP, 15 October 2008.

Ministerstwo Gospodarki (2014), Polska 2014. Raport o stanie handlu zagranicznego, Warszawa.

Moerman, G.A. (2008), Diversification in Euro Area Stock Markets: Country vs. Industry, Journal of International Money and Finance, Vol. 27, Issue 7, pp. 1122-1134.

Molle, W. (1995), Ekonomika Integracji Europejskiej. Teoria, praktyka, polityka., Fundacja Gospodarcza NSZZ Solidarność, Gdańsk.

Molle, W. (2011), European Economic Governance. The quest for consistency and effectiveness, Routledge Studies in the European Economy, Routledge, London and New York.

Molle, W. (2014), Competitiveness, EMU and Cohesion Experiences in the Past (2000-2013); Assessment of the Present (2014-2020) and Lessons for the Future (2020 and Beyond), International Journal of Management and Economics, No. 44, pp. 39-51.

Mundell, R. (1961), A Theory of Optimal Currency Areas, American Economic Review, No.51, pp. 657-665.

Nitsch, V., Pisu M. (2008), Scalpel, Please! Dissecting the Euro's Effect on Trade, ETH Zurich and National Bank of Belgium.

Pagano, M., von Thadden, E.-L. (2004), The European Bond Markets under EMU, Oxford Review of Economic Policy, Vol. 20, No. 4, pp. 531-554.

Schoenmaker, D., Bosch, T. (2008), Is the Home Bias in Equities and Bonds Declining in Europe?, Investment Management and Financial Innovations, Vol. 5, pp. 90-102.

Rose, A.K. (2008), EMU, Trade and Business Cycle Synchronization: What Do We Know and What Does it Mean for Poland?, (presentation) at the Common Currency and its Future: Lessons for the New Member States Conference, NBP, 15 October 2008.

Sorensen, B., Wu Y.-T., Yosha, O., Zhu, Y. (2006), Home Bias and International Risk Sharing: Twin Puzzles Separated at Birth, CEPR Discussion Paper, No. 5113. 
Tavlas, G.S. (1993), The,New’ Theory of Optimum Currency Areas, The World Economy, Vol. 16, No. 6. pp. 663-685. TFEU (2010), Treaty on the Functioning of the European Union, Title VIII: Economic and Monetary Policy.

Vaubel, R. (1988), Monetary Integration Theory, in: G. Zis (ed.), International Economics, Surveys in Economics, Longman, pp. 223-262.

Vaubel, R. (1990), Currency Competition and European Monetary Integration, The Economic Journal, Vol.100, No. 402, pp. 936-945.

\section{Appendix A}

TABLE 1A. Bilateral sectoral dissimilarity index S(ij) - 2003 vs. 2008

\begin{tabular}{|l|r|r|r|r|r|r|r|r|r|r|r|r|r|r|r|r|}
\hline 2003-2008 & AUT & BEL & EST & FIN & FRA & DEU & GRC & IRL & ITA & LUX & NED & PRT & SVK & SVN & ESP & POL \\
\hline Austria & $0 \%$ & $2 \%$ & $-1 \%$ & $-2 \%$ & $3 \%$ & $2 \%$ & $4 \%$ & $-4 \%$ & $-1 \%$ & $5 \%$ & $-2 \%$ & $4 \%$ & $7 \%$ & $-4 \%$ & $-1 \%$ & $3 \%$ \\
\hline Belgium & $2 \%$ & $0 \%$ & $-6 \%$ & $1 \%$ & $2 \%$ & $7 \%$ & $-7 \%$ & $-7 \%$ & $4 \%$ & $1 \%$ & $-3 \%$ & $-1 \%$ & $9 \%$ & $1 \%$ & $-6 \%$ & $4 \%$ \\
\hline Estonia & $-1 \%$ & $-6 \%$ & $0 \%$ & $1 \%$ & $0 \%$ & $0 \%$ & $8 \%$ & $-4 \%$ & $-5 \%$ & $1 \%$ & $-11 \%$ & $-4 \%$ & $4 \%$ & $-9 \%$ & $-8 \%$ & $7 \%$ \\
\hline Finland & $-2 \%$ & $1 \%$ & $1 \%$ & $0 \%$ & $2 \%$ & $-4 \%$ & $-2 \%$ & $3 \%$ & $-2 \%$ & $7 \%$ & $-3 \%$ & $-1 \%$ & $7 \%$ & $3 \%$ & $-6 \%$ & $1 \%$ \\
\hline France & $3 \%$ & $2 \%$ & $0 \%$ & $2 \%$ & $0 \%$ & $6 \%$ & $-7 \%$ & $-7 \%$ & $4 \%$ & $3 \%$ & $3 \%$ & $0 \%$ & $11 \%$ & $6 \%$ & $-2 \%$ & $8 \%$ \\
\hline Germany & $2 \%$ & $7 \%$ & $0 \%$ & $-4 \%$ & $6 \%$ & $0 \%$ & $1 \%$ & $-1 \%$ & $2 \%$ & $6 \%$ & $2 \%$ & $3 \%$ & $5 \%$ & $1 \%$ & $-2 \%$ & $2 \%$ \\
\hline Greece & $4 \%$ & $-7 \%$ & $8 \%$ & $-2 \%$ & $-7 \%$ & $1 \%$ & $0 \%$ & $-2 \%$ & $-1 \%$ & $7 \%$ & $-7 \%$ & $-3 \%$ & $12 \%$ & $1 \%$ & $4 \%$ & $6 \%$ \\
\hline Ireland & $-4 \%$ & $-7 \%$ & $-4 \%$ & $3 \%$ & $-7 \%$ & $-1 \%$ & $-2 \%$ & $0 \%$ & $-8 \%$ & $0 \%$ & $-9 \%$ & $-5 \%$ & $16 \%$ & $5 \%$ & $-2 \%$ & $5 \%$ \\
\hline Italy & $-1 \%$ & $4 \%$ & $-5 \%$ & $-2 \%$ & $4 \%$ & $2 \%$ & $-1 \%$ & $-8 \%$ & $0 \%$ & $5 \%$ & $-1 \%$ & $-1 \%$ & $9 \%$ & $-1 \%$ & $-3 \%$ & $5 \%$ \\
\hline Luxembourg & $5 \%$ & $1 \%$ & $1 \%$ & $7 \%$ & $3 \%$ & $6 \%$ & $7 \%$ & $0 \%$ & $5 \%$ & $0 \%$ & $1 \%$ & $1 \%$ & $10 \%$ & $4 \%$ & $2 \%$ & $7 \%$ \\
\hline Netherlands & $-2 \%$ & $-3 \%$ & $-11 \%$ & $-3 \%$ & $3 \%$ & $2 \%$ & $-7 \%$ & $-9 \%$ & $-1 \%$ & $1 \%$ & $0 \%$ & $2 \%$ & $4 \%$ & $-1 \%$ & $-5 \%$ & $3 \%$ \\
\hline Portugal & $4 \%$ & $-1 \%$ & $-4 \%$ & $-1 \%$ & $0 \%$ & $3 \%$ & $-3 \%$ & $-5 \%$ & $-1 \%$ & $1 \%$ & $2 \%$ & $0 \%$ & $11 \%$ & $0 \%$ & $-2 \%$ & $8 \%$ \\
\hline $\begin{array}{l}\text { Slovak } \\
\text { Republic }\end{array}$ & $7 \%$ & $9 \%$ & $4 \%$ & $7 \%$ & $11 \%$ & $5 \%$ & $12 \%$ & $16 \%$ & $9 \%$ & $10 \%$ & $4 \%$ & $11 \%$ & $0 \%$ & $3 \%$ & $2 \%$ & $0 \%$ \\
\hline Slovenia & $-4 \%$ & $1 \%$ & $-9 \%$ & $3 \%$ & $6 \%$ & $1 \%$ & $1 \%$ & $5 \%$ & $-1 \%$ & $4 \%$ & $-1 \%$ & $0 \%$ & $3 \%$ & $0 \%$ & $-6 \%$ & $-6 \%$ \\
\hline Spain & $-1 \%$ & $-6 \%$ & $-8 \%$ & $-6 \%$ & $-2 \%$ & $-2 \%$ & $4 \%$ & $-2 \%$ & $-3 \%$ & $2 \%$ & $-5 \%$ & $-2 \%$ & $2 \%$ & $-6 \%$ & $0 \%$ & $6 \%$ \\
\hline Poland & $3 \%$ & $4 \%$ & $7 \%$ & $1 \%$ & $8 \%$ & $2 \%$ & $6 \%$ & $5 \%$ & $5 \%$ & $7 \%$ & $3 \%$ & $8 \%$ & $0 \%$ & $-6 \%$ & $6 \%$ & $0 \%$ \\
\hline
\end{tabular}

S o u r c e : own calculations based on OECD data, GDP data (decomposition of Gross value added at basic prices, total activity, ISIC Rev 4 (10 industries breakdown). 


\section{Appendix B}

TABLE 2B. Bilateral sectoral dissimilarity index S(ij) - 2008 vs. 2013

\begin{tabular}{|l|r|r|r|r|r|r|r|r|r|r|r|r|r|r|r|r|}
\hline 2008-2013 & AUT & BEL & EST & FIN & FRA & DEU & GRC & IRL & ITA & LUX & NED & PRT & SVK & SVN & ESP & POL \\
\hline Austria & $0 \%$ & $5 \%$ & $-3 \%$ & $2 \%$ & $-3 \%$ & $-1 \%$ & $8 \%$ & $11 \%$ & $2 \%$ & $2 \%$ & $8 \%$ & $1 \%$ & $-4 \%$ & $4 \%$ & $0 \%$ & $6 \%$ \\
\hline Belgium & $5 \%$ & $0 \%$ & $10 \%$ & $-3 \%$ & $-3 \%$ & $4 \%$ & $14 \%$ & $10 \%$ & $4 \%$ & $-3 \%$ & $1 \%$ & $6 \%$ & $0 \%$ & $2 \%$ & $4 \%$ & $10 \%$ \\
\hline Estonia & $-3 \%$ & $10 \%$ & $0 \%$ & $-4 \%$ & $2 \%$ & $-2 \%$ & $10 \%$ & $13 \%$ & $8 \%$ & $8 \%$ & $13 \%$ & $6 \%$ & $-8 \%$ & $5 \%$ & $7 \%$ & $-2 \%$ \\
\hline Finland & $2 \%$ & $-3 \%$ & $-4 \%$ & $0 \%$ & $-10 \%$ & $5 \%$ & $4 \%$ & $14 \%$ & $-1 \%$ & $1 \%$ & $0 \%$ & $-2 \%$ & $4 \%$ & $7 \%$ & $-8 \%$ & $12 \%$ \\
\hline France & $-3 \%$ & $-3 \%$ & $2 \%$ & $-10 \%$ & $0 \%$ & $0 \%$ & $11 \%$ & $9 \%$ & $1 \%$ & $-1 \%$ & $3 \%$ & $1 \%$ & $-7 \%$ & $-3 \%$ & $-7 \%$ & $4 \%$ \\
\hline Germany & $-1 \%$ & $4 \%$ & $-2 \%$ & $5 \%$ & $0 \%$ & $0 \%$ & $10 \%$ & $2 \%$ & $5 \%$ & $3 \%$ & $5 \%$ & $-4 \%$ & $-7 \%$ & $-6 \%$ & $-6 \%$ & $2 \%$ \\
\hline Greece & $8 \%$ & $14 \%$ & $10 \%$ & $4 \%$ & $11 \%$ & $10 \%$ & $0 \%$ & $15 \%$ & $6 \%$ & $11 \%$ & $15 \%$ & $1 \%$ & $3 \%$ & $9 \%$ & $-1 \%$ & $16 \%$ \\
\hline Ireland & $11 \%$ & $10 \%$ & $13 \%$ & $14 \%$ & $9 \%$ & $2 \%$ & $15 \%$ & $0 \%$ & $12 \%$ & $11 \%$ & $7 \%$ & $18 \%$ & $2 \%$ & $6 \%$ & $15 \%$ & $13 \%$ \\
\hline Italy & $2 \%$ & $4 \%$ & $8 \%$ & $-1 \%$ & $1 \%$ & $5 \%$ & $6 \%$ & $12 \%$ & $0 \%$ & $3 \%$ & $8 \%$ & $-3 \%$ & $-4 \%$ & $3 \%$ & $-2 \%$ & $8 \%$ \\
\hline Luxembourg & $2 \%$ & $-3 \%$ & $8 \%$ & $1 \%$ & $-1 \%$ & $3 \%$ & $11 \%$ & $11 \%$ & $3 \%$ & $0 \%$ & $1 \%$ & $10 \%$ & $-3 \%$ & $2 \%$ & $6 \%$ & $6 \%$ \\
\hline Netherlands & $8 \%$ & $1 \%$ & $13 \%$ & $0 \%$ & $3 \%$ & $5 \%$ & $15 \%$ & $7 \%$ & $8 \%$ & $1 \%$ & $0 \%$ & $7 \%$ & $-1 \%$ & $3 \%$ & $8 \%$ & $7 \%$ \\
\hline Portugal & $1 \%$ & $6 \%$ & $6 \%$ & $-2 \%$ & $1 \%$ & $-4 \%$ & $1 \%$ & $18 \%$ & $-3 \%$ & $10 \%$ & $7 \%$ & $0 \%$ & $-1 \%$ & $3 \%$ & $-4 \%$ & $3 \%$ \\
\hline $\begin{array}{l}\text { Slovak } \\
\text { Republic }\end{array}$ & $-4 \%$ & $0 \%$ & $-8 \%$ & $4 \%$ & $-7 \%$ & $-7 \%$ & $3 \%$ & $2 \%$ & $-4 \%$ & $-3 \%$ & $-1 \%$ & $-1 \%$ & $0 \%$ & $0 \%$ & $-1 \%$ & $-3 \%$ \\
\hline Slovenia & $4 \%$ & $2 \%$ & $5 \%$ & $7 \%$ & $-3 \%$ & $-6 \%$ & $9 \%$ & $6 \%$ & $3 \%$ & $2 \%$ & $3 \%$ & $3 \%$ & $0 \%$ & $0 \%$ & $4 \%$ & $7 \%$ \\
\hline Spain & $0 \%$ & $4 \%$ & $7 \%$ & $-8 \%$ & $-7 \%$ & $-6 \%$ & $-1 \%$ & $15 \%$ & $-2 \%$ & $6 \%$ & $8 \%$ & $-4 \%$ & $-1 \%$ & $4 \%$ & $0 \%$ & $4 \%$ \\
\hline Poland & $6 \%$ & $10 \%$ & $-2 \%$ & $12 \%$ & $4 \%$ & $2 \%$ & $16 \%$ & $13 \%$ & $8 \%$ & $6 \%$ & $7 \%$ & $3 \%$ & $-3 \%$ & $7 \%$ & $4 \%$ & $0 \%$ \\
\hline
\end{tabular}

S o u r c e : own calculations based on OECD data, GDP data (decomposition of Gross value added at basic prices, total activity, ISIC Rev 4 (10 industries breakdown). 